School of Finance

University of St.Gallen

IMMIgRATION, REAl Estate PRICES AND THE

CONSUMPTION DECISIONS OF NATIVE HOUSEHOLDS

ZeNO ADAMS

KRISTIAN BLICKLE

WORKING PAPERS ON FINANCE NO. 2016/15

SWISS INSTITUTE OF BANKING AND FINANCE (S/BF - HSG)

JUNE 2016 


\title{
IMMIGRATION, REAL ESTATE PRICES AND THE CONSUMPTION DECISIONS OF NATIVE HOUSEHOLDS*
}

\section{Zeno Adams $^{+}$and Kristian Blickle ${ }^{\perp}$}

First distributed: May 2016

This version: May 2016

[Preliminary, please do not cite without permission - comments are very welcome]

\begin{abstract}
:
Since house prices govern the consumption decisions of renters and owners alike, changing house prices can have far-reaching macroeconomic consequences. We analyze how the disposable income and consumption decisions of households are affected by exogenous house price changes in Switzerland. We look at consumption of both housing and non-durable goods to establish a comprehensive picture. We ensure that our house price variation is exogenous by instrumenting house prices with origin-shift immigration. Our unique dataset includes information on every immigrant that entered Switzerland between 1990 and 2013, house price data for every community, and detailed survey data for over 5000 households. We can show three things. Firstly, different types of immigrants influence house prices to different degrees. This finding allows us to structure a valid instrument while also contributing to an ongoing European discussion over the effects of immigration. Secondly, rising house prices reduce the disposable income of renters. This is particularly pronounced for renters who are forced to relocate in times of rising prices. We find, therefore, that renters consume less while owners do not necessarily consume more. This is different from the US/UK context and may reflect the inability of households to extract home equity in central Europe. Thirdly, households transition to ownership less frequently or move away more often following an exogenous price increase. We add novel insights on household consumption and tenure-/location choice in response to exogenous changes in the cost of housing.
\end{abstract}

JEL codes: D14, D9, J61, R21, R23

Key words: immigration, home ownership, consumption, house prices, gentrification

\footnotetext{
* We would like to thank Martin Brown, Stefan Fahrländer, Matti Keloharju, Thomas Spycher, and seminar participants at the University of St. Gallen. We would also like to explicitly thank Stefan Fahrländer for detailed house price data. All remaining errors are our own.

+ University of St. Gallen, Chair of Real Estate Finance, Email: zeno.adams@unisg.ch

$\perp$ University of St. Gallen, Chair of Banking and Finance, Email: kristian.blickle@unisg.ch
} 


\section{Introduction}

How households respond to changes in the price of real estate is a fundamental question that ties together various strands of finance. Owners of homes that experience a price appreciation may be able to spend more on consumption goods and services. This is because they can either (re-) mortgage their home/obtain a loan to extract equity or consume out of a perceived wealth effect (Mian, Rao, \& Sufi, 2011; Campbell \& Cocco, 2007; Ortalo-Magne \& Rady, 2006). The degree to which owners respond to changes in house prices will depend upon legal and cultural frameworks that govern home equity borrowing. Renters, however, will feel the price pressure directly. They will be forced to either consume less, as they pay for more expensive accommodation, or move away to a less desirable area. Real estate prices thereby govern the tradeoff between consumption of goods and housing. This paper analyzes how disposable income, a household's location-/tenure choice and a household's consumption of goods and services relate to changes in house prices. Given their intertwined nature, an analysis of consumption can never be wholly independent of an analysis of tenure-/location choice. We focus on Switzerland for three reasons. Firstly, as in most central European countries, the propensity to extract housing wealth for private consumption is very low. A study of how owners react to changes in prices in this context provides new information to policy makers and academics. Secondly, highly detailed data on the housing market and household decisions is available for several years. Lastly, we are able to make use of an instrument for house prices, which has garnered significant political attention in Europe recently: exogenous immigration.

It is necessary to instrument house prices for two reasons. On the one hand, one may be faced with endogeneity concerns. Consumption (especially consumption of housing) can drive house prices at the local level. In a similar vein, both consumption and house prices could be driven by an omitted variable, such as local economic activity (King, 1990). On the other hand, if one subscribes to the permanent income hypothesis, households must suffer an unexpected change in wealth in order to change consumption. Any change in house prices, which has been anticipated by households ex-ante, should already be reflected in long-term consumption behavior (Deaton, 1992). Disentangling household expectation from actual price appreciation can be difficult without instruments that represent exogenous house price shocks.

A common instrument for house prices in US studies is the "land supply variable" first designed by Saiz (2010). Unfortunately, this instrument does not vary inter-annually, making it suitable only 
for cross-sectional analyses that cover longer periods of time. We make use of detailed data on annual immigration into Switzerland to instrument yearly changes in house prices at the community level. To disentangle the "pull" of attractive regions, we focus on shift-share or "pushed" immigration, as discussed in Card (2001). This immigration is orthogonal to other factors that may drive real estate price growth. We then relate instrumented house prices to consumption and location/tenure choice of households. Given the detail inherent to our data, we control for household-level time-varying confounders and fixed effects. We are able to show:

(1) Exogenous immigration can shape real estate prices. However, different types of immigrants (i.e. differencing by country of origin or residency-status) have very different impacts on these prices. Especially skilled immigrants can drive up prices considerably.

(2) Household disposable income and actual consumption are affected (negatively) by rising house prices. We find, however, that this applies primarily to renters. A $1 \%$ increase in house prices will reduce disposable income of renters by as much as $0.1 \%$-points, while leaving owners unaffected. This is effect is most pronounced among households that move into or within regions experiencing strong price growth. Although our measures are unspecific, we do not find that owners consume more, following rising prices.

(3) Households are incentivized to move away and less likely to buy a home, following a price appreciation in their native community. This effect is more pronounced for households which have recently married, divorced or had children (i.e. households with high expenditures). A $1 \%$ increase in house prices will increase the probability that an average household moves to a cheaper area by $0.8 \%$-points. It will also decrease the probability that a household transitions to ownership by $0.19 \%$-points.

Point (1) is important for two reasons. Firstly, it allows us to add a little to an ongoing policy debate that is currently highly relevant for Europe. We are able to show, for example, that refugees (of whom Switzerland saw a large influx during the early 1990's) reduce the average house price somewhat $(0.03 \%$ per $1 \%$ increase in refugees, relative to the local population). This effect, it should be mentioned, is dwarfed by the positive effect of skilled immigrants. Secondly, (1) shows that "total immigration" is insufficient as an instrument for house prices. In order to avoid issues with instrumentation (discussed below), detailed immigration data, that can be sub-categorized, is necessary. 
We build upon several previous papers that relate consumption and house prices. Campbell and Coco (2005) use UK Micro data that tracks detailed consumption metrics. They find a positive effect of house prices on consumption of older home owners. We do not find that owners consume more, but rather that renters consume less. This difference may reflect the difficulty in extracting wealth from a house in Switzerland. We further extend their analysis by instrumenting house prices and using panel data to observe the consumption changes in individual households over time. Mian, Rao and Sufi (2011) look at the consumption drop following the crisis as a function of the wealth lost to the real estate crash in major MSA regions of the US. They find that poorer regions are more likely to include households that consume out of housing wealth. This, again, may reflect the nature of the data for the US; second mortgages are commonplace. In fact, in a previous study Mian and Sufi (2009) show that US house prices are correlated with an increase in household leverage as families borrow out of the value of their home. Mian et al. instrument house price changes with the Saiz land supply variable. We are able to extend their approach somewhat by looking at the tenurechoice/consumption decisions in relation to one another. Furthermore, we are able to use an instrument which allows our house price data to vary inter-annually. In an approach more similar to the one taken in this paper, Disney, Henley and Stears (2002) use panel data to examine the response of households to house price changes. Like us, they too find that the moving decision is an element of this response. They focus particularly on household saving behavior at retirement age. We thereby extend their approach by looking at a larger panel of households (by age) over a longer period. We additionally extend their approach by using more granular house price data and instrumented prices. In a different approach to the same basic question, Fisher, Otto and Voss (2010) analyze the cointegration relationship between consumption income and wealth in Australia. They find little relationship between housing wealth and consumption before 2004 and some afterward. Finally, Case, Quigley and Shiller (2005) look at data from a variety of countries and find strong evidence for a relationship between consumption and household wealth. While they include Switzerland in their analysis, they are forced to impute housing wealth. Moreover, unlike our study, they look at aggregate, as opposed to household-level, consumption.

Of course, our paper also adds to the literature on gentrification, as we can show that exogenous house price increases induce households to move. Guerrieri et al. (2013) show that shocks, to the demand for housing, change the composition of a town. Wealthy people gravitate toward one another (either following or causing a shift in house prices), pushing poorer households to the less 
attractive periphery of towns. Becker and Murphy (2003) also show that households sort into neighborhoods, concentrically, according to relative wealth. Sieg et al. (2004) go as far as to show that, following clean air regulation, parts of Los Angeles that experienced an improvement in air quality saw more substantial gentrification (in association with price growth). As opposed to the studies above, we make use of panel data that allows us to capture the entire consumption decision of individual households.

Lastly, we add to the literature that uses immigration as an instrument for house prices. Basten and Koch (2015) instrument real estate prices with pushed immigration in Switzerland. We build heavily upon their approach, extending it slightly by using more granular data. This allows us to instrument prices at the community level with immigration from various regions/countries. Degen and Fischer (2010) specifically analyzed the link between Swiss house prices and immigration. Similar to us, they find that immigration is a significant driver of house prices ${ }^{1}$. Importantly, they show that the tight Swiss housing market is susceptible to immigration-based demand shocks, thus motivating the use of our instrument. Many other studies have also analyzed the relationship between immigration and house prices for other countries. Saiz (2007), Fischer (2012), Gonzalez and Ortega (2013), Ley et al. (2013) and Accetturo et al. (2014), to name a few, specifically relate immigration or shift-share immigration to house prices and directly lay the foundation for its use as an instrument in this study.

Overall, our paper adds to the above mentioned literature in three main ways. Firstly, our detailed panel data allows us to reflect the intertwined nature of consumption and tenure choice. Secondly, our granular instrument allows us to analyze the effect of yearly changes in housing prices while fulfilling the key requirements of instrumental variables (see discussion below). Finally, we focus on Switzerland a country with a highly developed rental market and strict limitations regarding a household's ability to extract equity. Our results for Switzerland may prove informative for neighboring countries with similar rental markets, home equity laws and, most recently, high rates of immigration.

\footnotetext{
${ }^{1}$ They find an average effect of between $2 \%$ and $2.7 \%$ for an increase of $1 \%$ of the local population vs. our $1.26 \%$ for every $1 \%$ increase in the local population. Though it is important to highlight, that we use slightly different specifications and different data, covering more years and regions, but focusing on a single-year as opposed to a longer term effect.
} 
The remainder of this paper is structured as follows. Section 2 outlines our various data sources. Section 3 describes our methodology, elaborating on why detailed community-level immigration is a necessary and useful instrument for house prices. Section 4 details our results and discusses their implication. Section 5 briefly concludes.

\section{Data}

We combine data from several distinct sources at the community level. The different types of data are described below.

\subsection{Immigration into Switzerland}

We make use of a database that includes every immigrant arriving in Switzerland from 1991 to 2013. This data is provided by the Swiss Federal Statistical Office (Bundesamt für Statistik, BFS). The data records information on first-time arrivals, departures, as well as the movements of foreigners within Switzerland. Since the early 1990's, Switzerland has seen a large influx of migrants from various countries, arriving for vastly differing reasons. Many people from former Yugoslavia arrived during the Balkan wars, while in recent years, immigrants from Germany have come seeking economic opportunities. Seen relative to the local population, Switzerland has experienced high rates of immigration ${ }^{2}$. Accordingly, our database contains over 15-million individual entries.

The BFS tracks 7 key characteristics of each immigrant; date of birth, year of arrival (or year of movement within Switzerland), gender, country of origin, type of residency permit, and the municipality ("Gemeinde") in which the person is registered. Given that Switzerland (a relatively small country) is home to 2324 municipalities, our data is very granular. Unfortunately, we are unable to see which individuals belong to a single family. Nor do we have information on the occupation/type of employment pursued by the immigrant upon arrival. However, the residency permit offers some broad information that can be used to gauge their proclivity to buy or rent housing. Switzerland defines several categories of permits at the federal level. The B-category denotes people who have been given a work or study-permit for 5 years. Many first-time arrivals,

\footnotetext{
${ }^{2}$ According to data from the OECD, the average share of foreigners in Switzerland between 1992 and 2013 was $24 \%$, the second highest in Europe (behind Luxembourg). To put these numbers into context, neighboring Austria and Germany had foreigner shares of $14 \%$ and $12 \%$ over the same period.
} 
who have never lived in Switzerland, will receive this type of permit. These immigrants are unlikely to buy housing but will likely compete on the rental market for attractive properties. Persons with a C-category are long-term residents who have an unconditional right to remain in Switzerland. Some people with a C-category do buy properties. A-category permits were reserved for people residing in Switzerland (usually from neighboring countries) for a short period of time. This type of permit was phased out in 2002, as Switzerland joined the Schengen area. Typically, applicants would work for a few months in construction or agriculture jobs. EU-citizens that work for less than half a year (or commute regularly across the border) now no longer need a permit. In any case, it is unlikely that these people would consume substantial amounts of housing in Switzerland. Lpermits are also given to persons who work in Switzerland for less than a year. This category of permit is still active and is given to immigrants from beyond the EU or EU citizens who work for 9 months or more in Switzerland. Categories N, S and F, as well as several other categories for short-term residents, are given to refugees and other arrivals looking for asylum or shelter in Switzerland. Unfortunately, this last category was only introduced after 1993. This is not an issue for the main body of our analysis, which focuses on the years 1999 to 2013, but makes the interpretation of our extension (the influence of different types of immigrants on house prices) more difficult.

[Table 1 about here]

Table 1 shows the number of immigrants arriving ${ }^{3}$ and leaving in the year 2000. The data is split in three different ways. Panel A splits the arriving immigrants by age at arrival/departure. The largest group of arrivals are in prime working-age, between 25 and 35. Many older immigrants, however, depart (possibly returning to their country of origin) resulting in net emigration of persons above 50 years of age. Panel B splits immigrants by country of origin. Clearly, significant numbers of immigrants arrive from Germany and former Yugoslavia. However, we also see net emigration for persons from certain countries such as Spain or Italy. The number of immigrants from these countries in particular varies strongly over the years. Panel C splits arrivals by residency permit. Perhaps surprisingly, many long term residents (C-Permit holders) emigrated in the year 2000.

Although Switzerland experiences a net positive immigration, growth-rates can differ strongly depending on the region in question. Appendix 1 showcases the fact that some communities have

\footnotetext{
${ }^{3}$ These figures include some immigrants that are upgraded from one category of permit to another.
} 
significant immigrant inflow, while others see a net outflow. This in particular, is crucial for our instrumentation and will be discussed in detail below. We primarily make use of immigration at the local scale. Looking at raw immigrant flows, we can see that major cities or larger communities see a much larger share of all movement. The same number of immigrants can be easily absorbed into the housing markets of large cities but would have a significant price effect in small towns. In subsequent sections, we therefore set number of immigrants in relation to total local inhabitants in order to avoid biasing the regression strongly toward major cities.

Similarly, some regions see large influxes of temporary workers. These are netted out when we look at net-immigration. However, when looking separately at immigration and emigration, we winsorize immigrants/emigrants as a share of the local population at the $1 \%$ level. This avoids placing too much weight on extreme observations. This winsorization does not change our data, shifting average immigration, as a share of the local population, from 3.46 to $3.12 \%$. AppenixFigure 1 Panel A showcases immigration per county when winsorized and when not. Panel B displays the distribution of net immigration.

\subsection{Swiss Real Estate Prices and Real Estate Supply}

We make use of Swiss real estate prices at the community-level from 1992 to 2013, provided by Fahrländer Partner Raumentwicklung (FPRE). Specifically, we make use of the sales prices for different types of houses in a community. To differentiate between quality and location attractiveness, we have access to high-, medium-, and low-price categories for each single family homes and single family apartments. FPRE further provide rental prices at the MS-level (slightly more aggregated than the community level) for all years and at the community level for later years of our sample. Missing rental prices at the community level are imputed from house prices at community level and rental prices at the MS level. The prices provided to us are based on actual sales data, combined with a hedonic pricing models developed by Fahrländer (Fahrländer, 2008; Fahrländer, 2006).

[Figure 1 about here]

[Figure 2 about here]

The agglomeration centers, such as Zurich, Basel and Geneva, enjoy extremely high prices in 2015 (see Figure 1). These regions also experience the most pronounced price growth over the years we 
measure. Conversely, some rural regions show limited price growth over time. Figure 2 shows two example communities, one of which experiences drastic price changes while the other sees relatively limited price developments. Across all communities in our sample, we have substantial cross sectional and time-series variation in house prices. We cover, after all, a period of price decline (in the early 1990s) as well as price growth (during the 2000s).

We combine data on house prices with data on the number of dwelling as well as the number of empty dwellings in each region. We are able to again differentiate by the type of abode. As such, we can compute a measure of "unused" housing for each type of house by "quality". Regions with significant stock of empty housing will perhaps see smaller changes in the price of real estate in response to immigration than regions with no excess capacity. The data on the number of available dwellings is collected by communities themselves but provided by the BFS.

\subsection{Swiss Household Panel}

In order to gauge household reactions to changes in the value of local real estate, we make use of the Swiss Household Panel (SHP). The SHP is based on surveys administered by FORS in Lausanne and covers the years 1999 to 2014 . The survey gathers information on where a household resides, whether it owns a home as well as some basic indicative data on consumption. It further includes details regarding the composition of households as well as information about income and sources of such income ${ }^{4}$.

The SHP data has several advantages. First, it has a very high retention rate; households appear in the survey for an average of 6 years. A high retention rate allows us to control for household level fixed effects as well as time-varying aspects of a household's composition in regressions. It is important to see, for instance, whether households change their behavior following a "life-changing event" such as the birth of a new child or death of a relative. Secondly, the survey includes information on a variety of topics that can help us isolate a clear effect in our regressions, discussed below. The survey records, for instance, information on a household's social origin.

[Table 2 about here]

\footnotetext{
${ }^{4}$ Tracking household financial information through self-reported surveys can be difficult, given the possibility that households may misreport data. However, the benefits of the data and its fount of information regarding other aspects of the household validate its use.
} 
Table 2 shows summary characteristics for a few variables of interest pertaining to household location and tenure choice. The table is based on nearly 13,000 individual households, located throughout Switzerland. The table tracks whether households relocate during their time in the sample and whether this relocation takes place because households move to less expensive areas. Similarly, we examine whether households transition to home ownership and in what areas. Given that relocation is a significant contributor to respondent attrition in surveys, these figures should be viewed as low estimates. As such, about $28 \%$ of our sample relocate $(38 \%$ of those who do not own a home at first observation); $7 \%$ of households move from expensive to less expensive areas. $14 \%$ of households in our sample transition to home ownership for the first time. On average, households are more likely to move (but also transition to ownership) if they are first observed in an area that experiences higher average price appreciation. This could be seen as first indicative evidence in favor of a displacement effect; households move because of rising prices. In order to investigate such a link more formally, it is necessary to control for some additional variables.

[Table 3 about here]

Table 3 shows a few explanatory variables. The table is based on over 73,000 household yearobservations of the nearly 13,000 individual households. Panel A depicts summary statistics while Panel B differences the summary statistics by whether households move. Controlling for these time-varying characteristics can be crucial to explaining the tenure and location choice of household in our sample, as the differences between the groups are statistically significant in every case.

[Table 4 about here]

Finally, Table 4, lists some of the consumption indicators of which we make use in this paper. Households do not, unfortunately, record actual consumption in sufficient detail to be of use to this investigation. Instead, we can make use of consumable income or "disposable income", which denotes total income less taxes and costs of living. These include all costs associated with the dwelling/real estate ${ }^{5}$. A second measure with which we gauge consumption is constructed from several individual questions that illicit household spending behavior. For instance, respondents can answer whether they go to the dentist, save into their $3^{\text {rd }}$ pillar retirement account, go on vacation

\footnotetext{
${ }^{5}$ These costs correlate strongly, though not perfectly, with annual fluctuations in real estate prices.
} 
(longer than a week), or go to dinner once a week ${ }^{6}$. We use responses to these questions (or combinations thereof) to create indices that reflect consumption behavior at a very rough level. An index composed of all answers allows us to track changes in material consumption in response to various influences, most critically, real estate prices.

\section{Methodology}

\subsection{Basic Specification}

We analyze the tenure-/location-choice decisions, disposable income and actual consumption of households in response to a house price shock. We attempt to relate consumption and tenure/location choice because the decision to consume less in order to rent in an expensive area is, after all, a single decision. Our analysis focuses on the years 1999 to 2013, for which we have house price, immigration, and survey data. In our basic analysis, we consequently estimate variations of the following regressions:

$1^{\text {st }}$ Stage: $H P_{t}^{r}=\beta_{1} Z_{t}^{r}+\beta_{2} D_{i t}+\beta_{3} X_{i t}+\beta_{4} \delta_{i}+\beta_{5} t+\beta_{6} \eta_{t}^{r}$

$2^{\text {nd }}$ Stage: $Y_{i t}^{r}=\beta_{1} \hat{H} P_{i t}^{r}+\beta_{2} \hat{H} P_{i t}^{r} * D_{i t}+\beta_{3} D_{i t}+\beta_{4} X_{i t}+\beta_{5} \delta_{i}+\beta_{6} t+\beta_{7} \eta_{t}^{r}$

$\mathrm{Z}$ is a vector of instruments, in this case immigration, discussed below. HP denotes the log of house prices in region $r$ in time $t . X_{i t}$ is a vector of time-varying characteristics for household $\mathrm{i}$ in time $\mathrm{t}$. $\mathrm{X}$ includes income, education, age, number of children, marriage and other information, depending on the specification. $\delta$ is a household-level fixed effect. $t$ is a time fixed effect ${ }^{7} . \eta$ are time varying regional characteristics such as past immigration or past house prices. These reflect past trends in a region and allow us to isolate effects of inter-annual changes in house prices. $\mathrm{Y}$ is our dependent variable of interest for household $\mathrm{i}$ in time $\mathrm{t}$ in region $\mathrm{r}$. We analyze several possible responses to rising house prices. In terms of tenure/-location choice, we look at a household's decision to: move

\footnotetext{
${ }^{6}$ The $3^{\text {rd }}$ pillar is a government sponsored retirement savings account in Switzerland

${ }^{7}$ Some regressions include a region fixed effect, though this changes the interpretation of some regressions.
} 
away or buy a home. In terms of non-housing consumption, we look at the money available for spending i.e. the disposable income as well as indices, detailing household purchases.

In some specifications, we interact house prices with indicator dummies. The estimator of interest in such regressions becomes $\beta_{3} H P_{t}^{r *} D_{i t}$. Where $\mathrm{D}_{\mathrm{it}}$ denotes whether a house has recently married, had new children, has a relatively high income, is young, or comes from a wealthy family. In specifications relating to non-durable consumption we look at indicators denoting whether a household owns a home and whether a household moves/relocates ${ }^{8}$. Our interactions can showcase how the estimators vary for sub-groups of the population with different consumption profiles or home owners behave differently from renters.

Since we estimate our variable of interest, and interact the estimated variable with an indicator, we must bootstrap our standard errors. To ensure our approach is valid, we further make use on an alternative but popular approach econometricians have used when faced with interactions of an instrumented variable and an exogenous regressor. We use predicted house prices and the interaction of predicted house prices as instruments for house prices and the interaction of house prices in an ordinary two stage IV. In effect, we therefore perform an IV with a zero-stage preestimation (Wooldridge 2002).

\subsection{Immigration as an instrument for house prices}

Many studies have documented some form of correlation between house prices and consumption in the past. These are discussed in the introduction above. However, a perusal of these papers shows that measuring a direct link between real estate prices and consumption can be difficult for two reasons, which are important in the context of this paper. (1) The relationship between raw house prices and consumption can be biased due to omitted variables and reverse causality. (2) Expected changes in prices might not induce a household to change its spending behavior.

Firstly, consumption may itself increase the price of local real estate by fueling economic activity. More directly, spillovers occur because housing consumption is part of the more general consumption basket. This applies particularly to consumption of housing at a very local level; in essence, individual house purchases may drive prices in our data. Similarly, though we control for

\footnotetext{
${ }^{8}$ Firstly, this allows us to determine whether the change in consumption, as a function of house prices, is different for renters than owners. Secondly, we can analyze the change in consumption specifically for households that choose to relocate.
} 
local economic activity to a certain degree, it is possible that economic activity, that is not observable to us, fuels both consumption and house price growth. For example, the arrival of a new company, which drives up future expected wages, may induce consumption of housing and consumable goods. Ultimately, ignoring this issue could lead to endogeneity problems and biased results.

The second important argument for the instrumentation of house prices was touched upon in the introduction above. Theoretically, households consume out of permanent income. According to the permanent income hypothesis, the consumption of a household at any one time will depend not on current, but on expected lifetime earnings. As a corollary, changes to house prices, which are anticipated by the households ex ante, should precipitate no change in consumption (Campbell \& Cocco, 2007; Deaton, 1992). Any anticipated wealth or income gain should already be reflected in current consumption ${ }^{9}$. It is difficult to measure a household's expectations concerning the real estate market; instead, one needs an instrument to capture unexpected variation in house prices. We make use of immigration as an instrument, as employed in the Swiss context in Basten and Koch (2015).

In order to serve as an adequate instrument for house prices, immigration has to effect permanent and unexpected changes in house prices without influencing individual household consumption itself. The relationship between prices and immigration is simple; immigration increases demand for housing. It does so either directly, because immigrants buy houses or indirectly, because immigrants drive up rental rates and induce local inhabitants to buy houses. In our data, rents and house prices show high levels of comovement over time. This is not surprising since the value of a property and hence its price is determined by the cash flow streams of current and future rents. The more immigrants arrive, relative to the native population, the more demand is created and the more house prices should react.

There is no direct reason as to why inter-annual immigration should change household consumption of goods and services. Consumption expenditure is a household-level decision that does not depend on annual changes in neighborhood composition. However, there is some argument to be made for the case that immigration influences household tenure choice. Especially

\footnotetext{
${ }^{9}$ This may not hold if a household is unable to access credit to the full extent. See Blickle \& Brown (2016) for a discussion of the housing market related impediments of borrowing constraints.
} 
households that take a negative view of immigration may be incentivized to move away due to a large number of immigrants residing in their community. We argue, however, that this decision is not necessarily based on annual fluctuations in immigration. We therefore control for past immigration patterns by including the share of immigrants already residing in a community in a given year in our analyses. This allows us to capture household preferences for relocation that are shaped by the neighborhood's composition. Sudden new arrivals will not yet have had the time to change someone's opinion of the area, while influencing the price directly.

At this point, it is worth highlighting an important feature of our data that pertains to accurate instrumentation of house prices. Not all immigrants will necessarily have the same impact on prices. In particular, immigrants with a short-term residency permit and low- paying jobs may not consume the same amount of housing as immigrants with long-term residency permits and wellpaying jobs. If different types of immigrants cluster in different communities, house price changes in response to immigration may be very varied across affected communities. This presents us with an opportunity. As discussed above, we are able to differentiate between immigrants with different residency permits as well as immigrants coming from different countries of origin. If we wish to claim that the effect of our instrument is, ceteris paribus, the same in each community (i.e. more immigration leads to a uniform increase in house prices), differentiation of immigrants is necessary. Ignoring the issue and focusing instead on total net immigration, would inherently accept "defiers" into our estimation of the local average treatment effect. Defiers are observations (in this case regions) that do not change corresponding to the instrument ${ }^{10}$ (i.e. regions whose price does not react/falls when immigrants arrive). The use of different instruments that accurately capture the heterogeneous price-pressure of different immigrants is an advantage of our paper.

Unfortunately, one final issue persists. The characteristics of some regions may attract immigrants. House prices, in particular, may be both affected by and a reason for immigration. Moreover, changes in local economic activity, which affect house prices, may affect immigration as well. It is therefore necessary to make use of exogenous or "origin-push" or "shift share" immigration as opposed to raw immigration in our study.

\footnotetext{
${ }^{10}$ see Imbens and Wooldridge NBER lecture (2007) for a more detailed discussion.
} 


\subsection{Shift-share immigration}

The methodology was first developed by Card (2001) and used in the Swiss context by Basten and Koch (2015) (discussed above). It makes an assumption about the likely distribution of immigrants based on their ethnicity in order to circumvent the "pull" of more attractive regions. Specifically, it asserts, immigrants are likely to congregate around people of their ethnicity ${ }^{11}$. In order to determine exogenous immigration one assumes, therefore, that current immigrants will move to the same area as previous immigrants from similar regions.

We make use of historical immigration rates from the early 90s, averaging 3 years from 1990 to 1992, as a baseline. We then assume that each community in Switzerland will receive the same percentage-share of persons from certain countries or, alternatively, country-groups going forward. This does not change the actual number of immigrants entering Switzerland; it merely changes the allocation. As such, we capture the exogenous "push" that induces immigrants to leave their homeland but avoid the confounding effects of the "pull" of attractive communities.

An example may help to illustrate the concept. The share of Germans entering Zurich was lower in 1990 than in 2010. The total number of German immigrants actually entering Zurich in 2010 was 4688 . Using historic distribution of immigrants, however, we allocate 3574 immigrants to Zurich from Germany according to the shift-share methodology. The rest are distributed to other regions that were more popular amongst German immigrants in the early 1990s.

Ultimately, we make use of two sets of instruments in our regressions; one in the main body of our analysis and one alternate set in the robustness section. Our baseline instruments are shift-share immigration and emigration, separately, for 4 major country groups. We thereby look at immigration/emigration from Western Europe (excl. Portugal), Eastern Europe (incl. Portugal), remaining wealthy OECD states and the rest of the world. This separation allows us to capture the differential effects that some immigrants exert on house prices. Moreover, using broader categories avoids interpreting the effects of very small groups of immigrants from some countries. In the robustness section we look at shift-share immigration and emigration (separately) for Germany,

\footnotetext{
${ }^{11}$ Bartel (1989) shows that immigrants tend to be more geographically concentrated than comparable natives of the same age and ethnicity but that this geographic concentration is much lower among highly educated households.
} 
former Yugoslavia, France, Spain, Portugal, US, UK, Italy, Austria, Turkey, and the rest of the world.

\subsection{Extension: Immigration and House prices}

It is uncommon to attempt to interpret the first-stage of an IV regression, beyond testing the validity of excluded instruments. However, recent political discussions in Europe have centered on immigration and its various effects. We feel we are in a position to add to the discussion, given the depth of our data. As a consequence, we further estimate the relationship between pushed immigration and house prices in dedicated regressions. These are not used as first stages, but rather viewed independently. We estimate the following specifications as extensions for this paper:

$H P_{t}^{r}=\alpha_{1} Z_{t}^{r}+\alpha_{2} \theta_{t}^{r}+\alpha_{3} t+\alpha_{4} r$

HP denote the log of house prices. In this case $r$ is a community fixed effect, $t$ is a time fixed effect. theta are community-level controls such as the number of empty abodes for different size categories of houses (relative to the total in each category). $\mathrm{Z}$ is the factor of interest this time. We look at "pushed" immigration differenced by country of origin as well as residency permit.

However, the price in one region may relate to prices in neighboring regions. After all, prices do not immediately change drastically at the community border. Price changes in one community may beget a recursive spiral of price changes in neighboring communities, following an increase in demand. We consequently estimate a second specification that accounts for the possible relationship between various communities.

$H P_{t}^{r}=\left(I_{N} \otimes l_{T}\right) r+\rho\left(W_{N} \otimes I_{T}\right) H P_{t}^{r}+\beta X_{t}^{r}+\alpha Z_{t}^{r}+\varepsilon_{t}^{r}$

$\varepsilon_{t}^{r} \sim \operatorname{IID}\left(0, \sigma_{\varepsilon}^{2}\right)$

The above specification is a panel spatial autoregressive model that makes use of prices in surrounding communities to determine house prices in a community. The log of house prices, $H P_{t}^{r}$ , depend on a set of region specific effects $\mathrm{r}$, a spatial lag $\left(W_{N} \otimes I_{T}\right) H P_{t}^{r}$, the regressor matrix $\mathrm{X}$ and pushed immigration, $Z$. The region specific effects capture characteristics that vary across municipality but do not change over time. For instance, house prices in heavily urbanized areas such as Zurich city are higher on average than in more rural areas. House prices along the lake of 
Zurich are also known to be higher. The spatial lag $\left(W_{N} \otimes I_{T}\right) H P_{t}^{r}$ models the spatial dependence among house prices. The spatial lag coefficient $\rho$ measures the strength of spatial interactions and, for most practical applications, is in the range between 0 and 1. Ignoring the spatial interaction among regions carries the implicit assumption that a positive demand shock in one municipality increases house prices equally within that region but has no effect when crossing the border into another municipality. This strict assumption is unlikely to hold in practice. If ignored in the model, the spatial link between regions appears in the error term and leads to biased coefficient estimates (LeSage and Pace, 2009). Explicitly modeling the spatial interaction among regions not only avoids this bias but also allows to estimate house price spillovers among regions.

\section{Results}

We show that instrumented, exogenous and unexpected changes in house prices determine the amount of money available for consumption. Secondly, we show that these prices determine location- and tenure choice of households. Finally, we extend our analysis by showing, in detail, that different types of immigration may impact house prices in different ways.

\subsection{House prices and disposable income}

In table 5 we relate household disposable income to house prices and household characteristics. Disposable income is defined as income less taxes and self-reported expenditure on "housing", as a share of total income. As such, the variable is scaled to lie between 0 and 1 . Disposable income should change only if households experience rising rental prices, changes in mortgage payments due to the interest rate changes, or changes in the tax rate. Changing wages are accounted for in the regression as well as through our use of scaling. Changes in the cost of renting particularly affect households that do not own. Conversely, households that do own will be affected by rising interest payments on mortgages. However, rising interest rates will affect all households with floating rate mortgages in Switzerland at the same time. This is subsumed by a time fixed effect. Rental prices, on the other hand, can change at the local level and will affect households in different communities to different degrees. Tax rates, unfortunately, can vary at the federal, the cantonal and the community level. Very few communities in our sample change the tax burden during our analysis and we show below that our results are not dependent upon tax rate changes. 
[Table 5 about here]

In Column (1) we relate consumable income directly to the log of rental prices (referred to as "house prices" for simplicity). We show that a $1 \%$ increase in house prices leads directly to a $0.02 \%$-point drop in consumable income. Columns (2) - (7) employ an IV approach whereby we pre-estimate house prices using immigration as instruments and all other regressors. In column (2) we thereby show that an exogenous unexpected rise in house prices leads to an even larger drop in consumption; $0.09 \%$-points for every $1 \%$ rise in house prices. A country wide $10 \%$ increase in house prices, which does occur in our sample, would therefore have the potential to reduce aggregate consumption by almost 1 percentage points. This would put significant downward pressure on GDP growth.

We are interested in whether different types of households respond differently to changing house prices. For one, households that own a home should not see their disposable income affected by inter-annual changes in the rental prices of housing. We therefore use interaction terms in our regressions. We interact house prices with dummies, denoting whether a household owns (in column (3)) and whether the household from the time they are first observed (in column (4)). We find that these dummies cancel out the negative effect of rising house prices. We show, therefore, that the reduction in consumable income is felt particularly by renters.

We further look at whether the effect is stronger for households that move, households that are young and households that have wealthy parents. Whether a household is young or has wealthy parents should not (and does not) change the sensitivity of disposable income relative to changing house prices. These interactions are perhaps more important in the regression that analyzes actual consumption, discussed below. On the other hand, whether a household moves while in our sample may change its disposable income. After all, rental rates do not change immediately for existing contracts. The degree to which owners can raise the rents for existing tenants is limited. Households that move, however, will be strongly affected by changing rental rates as they have to sign new contracts that reflect current market rents. Column (5) shows the interaction of house prices and whether a household ever moves while in the sample. A significant determinant of changing disposable income is the propensity to move. If we separate this interaction term into households that move into cheaper areas and households that move within the same or into more expensive areas (results not reported for brevity), we find that the effect is driven largely by the latter group. 
Households that relocate see their disposable income fall by $0.04 \%$-points for every $1 \%$ increase in house prices ${ }^{12}$. This will naturally affect families with a high propensity to relocate. Especially families who change job, or have children (which may induce a move) in a time in which prices rise exogenously may find themselves disenfranchised.

Above, we state categorically that our results are not driven by tax rate-differences between municipalities or by changing tax rates within a municipality. We run two tests to help make this case. In one analysis we use gross income less cost of housing as our dependent variable. The results are reported in the appendix. We do not use this as our baseline, as we lose observations. Some households, it seems, do not report gross income. In the Appendix 2 Panel A we can show, however, that our results are not changed from what is reported above. In a second test we include municipality-level fixed effects in our regressions. The interpretation of the results changes slightly given that we now remove an average-municipality effect. Such a dummy would, however, capture time-invariant municipality-level tax rate influences. Overall, the results, reported in Panel B of Appendix 2, remain unchanged to the ones discussed above.

\subsection{House Prices and basic consumption indicators}

In table 6 we relate an index of consumption goods to house prices. We use the same approach and variables as in table 5 above, but vary the dependent variable. The consumption index denotes, in broadest terms, whether households consume more or less in response to house price changes (see description above). We do not interpret the coefficient magnitude directly, as not all the elements of the consumption index represent the same expenditures. Instead, we interpret the direction of the coefficients.

\section{[Table 6 about here]}

We show that rising house prices have a negative effect on consumption of households. This holds more strongly if we make use of the IV approach. In part, the difference between OLS and IV may reflect the different responses to anticipated vs. unanticipated house price changes. Again, households that own a home are not affected as strongly. There is no indication, however, that households who own consume more, following a price appreciation. They are simply "less

\footnotetext{
12 This effect is approximately $0.05 \%$-points for households that do not move to less expensive areas. Conversely, the effect is insignificant for households that do move to less expensive areas.
} 
affected". It should perhaps be noted, that we do not find differential effects for households that move. However, the measure is perhaps too broad to extrapolate deeper conclusions. We also do not find differing reactions from households that have wealthy parents. One might have expected such households to make up a temporary shortfall with borrowing (either from banks or parents) so as to not forego consumption. Again, our index may be too broad to capture such effects.

\subsection{The relationship between house prices and tenure-/location choice}

\subsubsection{House prices and tenure choice}

In table 7, we analyze a household's propensity to transition to ownership in relation to house prices. House prices are again proxied by the log of rental prices. We cut the data, so that a household is only observed until it transitions to ownership. As can be seen in column (1), a 1\% rise in house prices reduces a household's propensity to transition to ownership by about $0.07 \%$ points. If we instrument rising house prices with immigration, we find that the effect is even more pronounced. A $1 \%$ increase in house prices reduces the likelihood of transitioning to ownership by $0.17 \%$-points.

[Table 7 about here]

We further look at how the propensity to transition to ownership in response to house price changes is different in sub-groups of the population. We again include interaction terms between house prices and household characteristics, as described above. We focus on whether a household has married in $+/-1$ year, has children in in $+/-1$ year, has a primary respondent below 35 years of age, has income above $120,000 \mathrm{CHF}$, or has wealthy parents.

We find that households, who recently experienced a reason to spend more are indeed less likely to buy a home. We find, for instance, that the propensity to transition falls by an additional $0.09 \%$ pts in the years surrounding a marriage (from a baseline of about $-0.16 \%$-points) for every $1 \%$ increase in house prices. We observe a very similar effect in the years surrounding the new birth of a child. These families are likely more strapped for financial resources and therefore more sensitive to changes in the price of housing. In our data, marriage is often associated with the birth of a child after only a short time as well as one party dropping out of the labor force.

Conversely, we find that households who are wealthy or young are far less affected by rising house prices. Young households may be more willing than older counterparts to invest in ownership, 
despite exogenously rising prices. They likely expect long-term use of the dwelling, so that interannual price fluctuations in the near-term are less important. In a similar vein, wealthy households are far less influenced by price changes because the average increase is far less important to them than to a poorer household. Wealthy families can simply still afford home ownership. Lastly, households with wealthy parents show no markedly different reaction to changing house prices. It appears that such households do not draw upon their parents to make up a sudden shortfall due to rising prices.

[Table 8 about here]

We extend the above analysis by looking specifically at whether households transition to ownership in the same region in which they already reside. The negative effect of rising house prices should be more pronounced among this group, as some households may yet transition to ownership in cheaper areas. Table 8 reports our results, focusing on the coefficients of interest. Overall, the results are highly comparable to the results found in Table 7 , though slightly larger in terms of absolute magnitude.

[Table 9 about here]

Given the way we structure our data for this analysis, it is possible to estimate our effect of interest using a cox proportional hazard model. The results for a simple specification, that makes use of instrumented house prices, are shown in table 9. We find that higher house prices reduce the likelihood of transitioning to homeownership by almost 100\% (this varies between 90 and 96\%, depending on the exact specification). The hazard ratio of our key variable is reported in square brackets. However, it is perhaps important to clarify the scaling involved, since our $\mathrm{x}$ variable is $\log$-transformed with a base of $e$. We can say that households, which experience 2.7-times higher prices, are about $96 \%$ less likely to transition to ownership. The cox regression can therefore be viewed as an interesting thought experiment and a confirmation of our above results.

\subsubsection{House prices and location choice}

We show that households are displaced from their original neighborhoods due to rising rental prices. Specifically, we find evidence that households move to cheaper areas. We define such areas as ones in which the average house prices are lower than in the regions in which a household is initially observed. We do not truncate our data for these analyses, as a household can move multiple 
times while in our sample. However, we use the same variable setup as in the regressions above and exclude households that own at first observation from the regressions. Our results are reported in Table 10.

\section{[Table 10 about here]}

We find that a household is $0.25 \%$-points more likely to leave for a cheaper area following a $1 \%$ price increase. Using the exogenous price increases determined by our IV specification, we find even larger effects. A $1 \%$ increase in house prices causes an almost $1 \%$-point increase in the propensity to move away to a less expensive area. Interestingly, we find no real differences between groups of the population. Overall, we argue that rising house prices seem to be a universal incentive for households to relocate ${ }^{13}$.

\subsection{Robustness}

We perform several checks to determine the robustness of our results. The simplest step involves testing whether changing rental prices induce different reactions in households than changing house prices. To test this, we re-run some of the regressions above using house prices of mid-quality single family homes instead of rental prices. We still instrument these using pushed immigration from different regions, as before. The coefficients of interest are reported in Panels A and B of Appendix 3 and 4. We find that all our above results hold in the face of this slightly modified regression.

In a second analysis, we wish to test whether our instruments as well as our estimation techniques are valid. We can examine both these questions in a single step. We adopt the estimation technique discussed above and in Wooldridge (2002). We thereby pre-estimate our terms of interest and use these as instruments in a standard IV-framework. We additionally change the instruments we use for these analyses. We make use of origin-share immigration, as above. However, we now split immigrants according to their country of origin, as opposed to their region (or country group) of origin. Accordingly, we make use of 9 countries (Germany, former Yugoslavia, France, Spain, Portugal, Turkey, Austria, the US, and the UK) and one "rest of the world" bucket. We again split

\footnotetext{
${ }^{13}$ It is perhaps important to note that we do not find any effect of house prices on the average propensity to move; i.e. the propensity to move to any area regardless of housing cost (results not reported). This is likely due to the fact that we find a large negative influence of house prices on the likelihood of "transitioning up"; i.e. the likelihood of moving to a more expensive area. These effects possibly cancel one another out to a certain extent.
} 
emigration and immigration into separate components. The results of this approach are recorded in Appendix 5 and 6. We find no significant deviation from our results discussed above and take our original specification to be valid.

Finally, it is important to highlight the fact (again) that we make use of fixed effect regressions. This implies that only households who transition to ownership or move actually influence our results pertaining to tenure-/location choice (all others observations would be subsumed by the household-level fixed effect). Appendix 7 uses pooled OLS regressions to document household reactions. The results, though slightly weaker, still confirm our statements made above.

\subsection{Extension: The relationship between immigration and house prices}

We show that a strong relationship between house prices and immigration exists. Our instrument passes weak and under-identification tests. We use a variety of estimation techniques to not only prove this point, but make the relationship interpretable in a meaningful way. By looking beyond our first stage, using separate dedicated regressions, we show two things. Firstly, total net immigration is insufficient as an instrument for house prices. Heterogeneity in the impact of immigrants from different regions must be considered if we wish to create a viable instrument. Secondly, we are able contribute substantively to the ongoing policy debate regarding, among other things, the immediate effect of immigration on the housing market.

\section{[Table 11 about here]}

In table 11, we first relate immigration from different countries to the log of house prices using an OLS specification. The results are presented in Panel A. Of course, we make use of communitylevel fixed effects and time-fixed effects to factor out region- or time-specific trends. We further include time-varying regional characteristics such as the local vacancy rate. Our variables of interest are "net immigration", so we focus on displaying only those for simplicity. We show the effect of total net immigration in column (1), the effect of net immigration split by three major sources of immigrants in column (2). In column (3) we split immigration at the country-level. We make use of this same split when instrumenting house prices with immigration in the robustness section above; it represents our most detailed split. Net immigration is defined as the number of origin-shifted immigrants, relative to the local population, arriving in a year less those leaving in that year. We can see that a $1 \%$ increase in the number of immigrants, relative to the local population, raises house prices by $1.26 \%$. If we split this, column (2), we can see that the effect is 
primarily driven by German immigrants, while the effect for immigrants originating in former Yugoslavia is insignificant. It is possible that immigrants from Germany pursue higher paying employment, which leads to their driving up prices. Finally, if we look at a more granular split, we find very varied effects. Particularly, immigrants from Germany or former Yugoslavia, the two largest groups, have no real price-effect.

It is possible that a simple OLS specification biases our coefficients in this type of setting. Given the very close proximity of communities to one another, treating each as an individual isolated entity may lead to problems. Instead, we estimate our regressions again in an SAR framework. As such, we allow for the price dynamics in one region to affect prices in neighboring regions. The results of this specification are reported in Table 12.

\section{[Table 12 about here]}

We can see that the spatial lag coefficient is large and significant. This implies that relying on iid errors and ignoring a spatial correlation may indeed bias our results. We now find that immigrants from Germany have a positive, while immigrants from former Yugoslavia have a strongly negative effect on house prices. In column (3) we can see that the effect of immigrants from France, Spain, Portugal and the U.K. remains large and positive. Overall, net immigration from these countries is relatively low, however. A substantial net increase of the local population from one of these countries would be rare. This is one of the reasons we work with immigration from countrycategories in the analyses above. It is important to capture the fact that different types of immigrants have different effects, but we also do not wish to weight the effect of a limited number of immigrants too strongly. For information, the country category split is recorded in Appendix 8 .

\section{[Table $13 \& 14$ about here]}

Finally, tables $13 \& 14$ separate immigrants by the type of residency permit they hold. We remove all short-term permits from this analysis to ensure that we only capture the effects of immigrants who stay for more than a year ${ }^{14}$. We again perform an ordinary OLS analysis in table 13 , and a SAR analysis in table 14. Immigrants which receive B or C permits, i.e. the permission to stay longer, induce a much larger positive price movement. We find a slightly negative effect for

\footnotetext{
${ }^{14}$ Since we use net immigration in all other analyses, this should does not change the data substantially, although it does remove a few possibly erroneously coded observations.
} 
immigrants who receive permission to enter the country as refugees. This effect, however, is only significant in very few specifications. Overall, the positive effect of longer-term immigrants outweighs any possibly negative effects of refugees in this specification.

The above effects deserve a slightly more detailed discussion. Unfortunately, the separation of "short-term arrivals" into "short term workers" and "refugees" only began in 1993. This means we lose the early years of our data in the specifications displayed in Table 12, since we explicitly drop short term arrivals in this specification. Especially the years 1990-1992 saw a massive influx of immigrants from former Yugoslavian countries, most of whom arrived as refugees. It is possible, that some of the negative effect observed for immigrants of former Yugoslavia, above, would also translate to more sizeable negative effects for immigrants arriving as refugees. It may be that smallscale refugee immigration does not induce an effect, large scale immigration, however, might.

The above tables do highlight the point made in the methodology discussion above. It is necessary to separate out different types of immigration. Subsuming all types of immigration under the category "total" immigration may well lead to bias induced by the having regions that see falling prices and regions that see rising prices due to immigration in the same specification. Our detailed data, therefore, allows us to contribute to the use of immigration as an instrument for house prices.

\section{Conclusion}

This paper analyzes the influence house prices exert on consumption and tenure-/location choice of households in Switzerland. Given that a renter, faced with rising prices, must decide between consuming less and relocating, it is important to consider consumption and tenure-/location choice together. We make use of detailed household level panel data, elicited via surveys, communitylevel house prices and a database of all immigrants entering Switzerland. We use the latter to instrument local house prices at the community level with "pushed" immigration. This has two benefits. Firstly, it avoids endogeneity problems that may arise from using local house prices to determine local tenure choices. Secondly, it allows us to make sure house price changes are unexpected for local residents. Based on the permanent income hypothesis, expected price developments should have no influence on household behavior. 
This paper presents three main findings. First, household disposable income is reduced by rising house prices. This applies particularly to households that relocate in times of rising prices. Such households will be subjected to the full increase in prices while long-term renters, with established contracts, will be less affected. Moreover, we find that the disposable income of households who own are unaffected by rising prices. Although hampered by data limitations, we do not find that these households consume markedly more in the immediate time period around a wealth increase. Second, this paper finds households are more likely to relocate to cheaper areas following a price increase. Similarly, households are far less likely to transition to ownership in the face of exogenously higher prices. Especially households with a reason to consume more, such as those that recently had a child or engaged in marriage, will find it difficult to make a transition to ownership. Their disposable income is simply being channeled into purchases they cannot (chose to) forego. This finding contributes to the literature on gentrification, showing that the composition of owners (and renters) in an area is shaped by prices. Households that are less well off, naturally, as well as households with need to consume are displaced.

Finally, in an extension to the paper we show that different types of immigrants exert different pressure on house prices. Traditionally, when using instruments, one might only want to show that immigration is related to house prices. We seek to use our data to contribute to the ongoing political discussions concerning immigration. We therefore show that qualified immigrants with long termpermits have a strong positive influence on house prices.

Overall, we add to the debate about home ownership and consumption. Our findings have implications for researchers and policy makers alike; changes in house prices, induced by immigration or other sudden policy changes, will affect the distribution of home ownership in society as well as the composition of neighborhoods. Just as importantly, it will shape aggregate consumption by influencing household disposable income. In the face of rising prices, consumption might fall if owners do not consume more and renters consume less. 


\section{References}

Accetturo, A., Manaresi, F., Mocetti, S., \& Olivieri, E. (2014). Don't stand so close to me: The urban impact of immigration. Regional Science and Urban Economics, 45, 45-56.

Basten, C., \& Koch, C. (2015). The causal effect of house prices on mortgage demand and mortgage supply: Evidence from Switzerland. Journal of Housing Economics, 30, 1-22.

Bartel, A.P. (1989), “Where do New U.S. Immigrants Live?”, Journal of Labor Economics, 7(4), 371-391.

Becker, G., \& Murphy, K. (2003). Social Economics: Market Behavior in a Social Environment. Harvard University Press.

Blickle, K., Brown, M. (2016). Borrowing Constraints and Home Ownership. University of St. Gallen Working Paper

Campbell, J. Y., \& Cocco, J. F. (2007). How do house prices affect consumption? Evidence from micro data. Journal of Monetary Economics, 54(3), 591-621.

Campbell, J. Y., \& Mankiw, N. G. (1990). Permanent Income, Current Income, and Consumption. Journal of Business \& Economic Statistics, 8(3), 265-279.

Card, D. (2001). Immigrant Inflows, Native Outflows, and the Local Labor Market Impacts of Higher Immigration. Journal of Labor Economics, 19(1), 22-64.

Case, K. E. (2000), “Real Estate and the Macroeconomy”, Brookings Papers on Economic Activity

Case, K. E., Quigley, J. M., \& Shiller, R. J. (2005). Comparing Wealth Effects: The Stock Market versus the Housing Market. Advances in Macroeconomics, 5(1).

Deaton, A. (1992). Understanding Consumption. Clarendon Press - Oxford.

Degen, K., \& Fischer, A. M. (2010). Immigration and Swiss House Prices. SNB Working Paper, (November).

Disney, R., Henley, A., \& Stears, G. (2002). Housing costs, house price shocks and savings behaviour among older households in Britain. Regional Science and Urban Economics, $32(5), 607-625$.

Fahrländer, S. (2006). Semiparametric Construction of Spatial Generalized Hedonic Models for Private Properties. Swiss Journal of Economics and Statistics (SJES), 142(IV), 501-528.

Fahrlander, S. S. (2008). Indirect Construction of Hedonic Price Indexes for Private Properties. Swiss Journal of Economics and Statistics (SJES), 144(4), 607-630.

Fischer, A. M. (2012). Immigrant language barriers and house prices. Regional Science and Urban Economics, 42(3), 389-395.

Fisher, L. A., Otto, G., \& Voss, G. M. (2010). The response of Australian consumption to housing wealth. Journal of Macroeconomics, 32(1), 284-299. 
Gonzalez, L., \& Ortega, F. (2013). IMMIGRATION AND HOUSING BOOMS: EVIDENCE FROM SPAIN*. Journal of Regional Science, 53(1), 37-59.

Guerrieri, V., Hartley, D., \& Hurst, E. (2013). Endogenous gentrification and housing price dynamics. Journal of Public Economics, 100, 45-60.

Imbens, G., \& Wooldridge, J. (2007). Whats New in Econometrics? In Whats New in Econometrics? NBER Summer Institute. Retrieved from http://www.nber.org/minicourse3.html

King, M. (1990) Discussion of J. Muellbauer and A. Murphy; is the U.K. balance of payments sustainable? Economic Policy, 11, 383-87.

LeSage, J., \& Pace, K. (2009). Introduction to Spatial Econometrics. London: CRC Press.

Ley, D., Tutchener, J., \& Cunningham, G. (2002). Immigration, Polarization, or Gentrification? Accounting for Changing House Prices and Dwelling Values in Gateway Cities. Urban Geography, 23(8), 703-727.

Mian, A. R., Rao, K., \& Sufi, A. (2011). Household Balance Sheets, Consumption, and the Economic Slump. SSRN Electronic Journal.

Mian, A., \& Sufi, A. (2009). The consequences of mortgage credit expansion : evidence from the u . S . Mortgage default crisis. Quarterly Journal of Economics, 1449-1496.

OECD (2016), Foreign-born population data, retrieved from https://data.oecd.org/migration/foreign-born-population.htm

Ortalo-Magne, F., \& Rady, S. (2006). Housing Market Dynamics: On the Contribution of Income Shocks and Credit Constraints*. Review of Economic Studies, 73(2), 459-485.

Saiz, A. (2007). Immigration and housing rents in American cities. Journal of Urban Economics, $61(2), 345-371$.

Saiz, A. (2010). The Geographic Determinants of Housing Supply *. Quarterly Journal of Economics, 125(3), 1253-1296.

Sieg, H., Smith, K., Banzhaf, S., \& Walsh, R. (2004). Estimating the general Equilibrium Benefits of Large Changes in Spatially Delineated Public Goods. International Economic Review, 45(4), 1047-1077.

Sinai, T., \& Souleles, N. S. (2005). Owner-Occupied Housing as a Hedge Against Rent Risk. The Quarterly Journal of Economics, 120(2), 763-789.

Wooldridge, J. M. (2002). Econometric Analysis of Cross Section and Panel Data. Cambridge, Massachusetts: The MIT Press. 
Prices of single-family homes in 2015

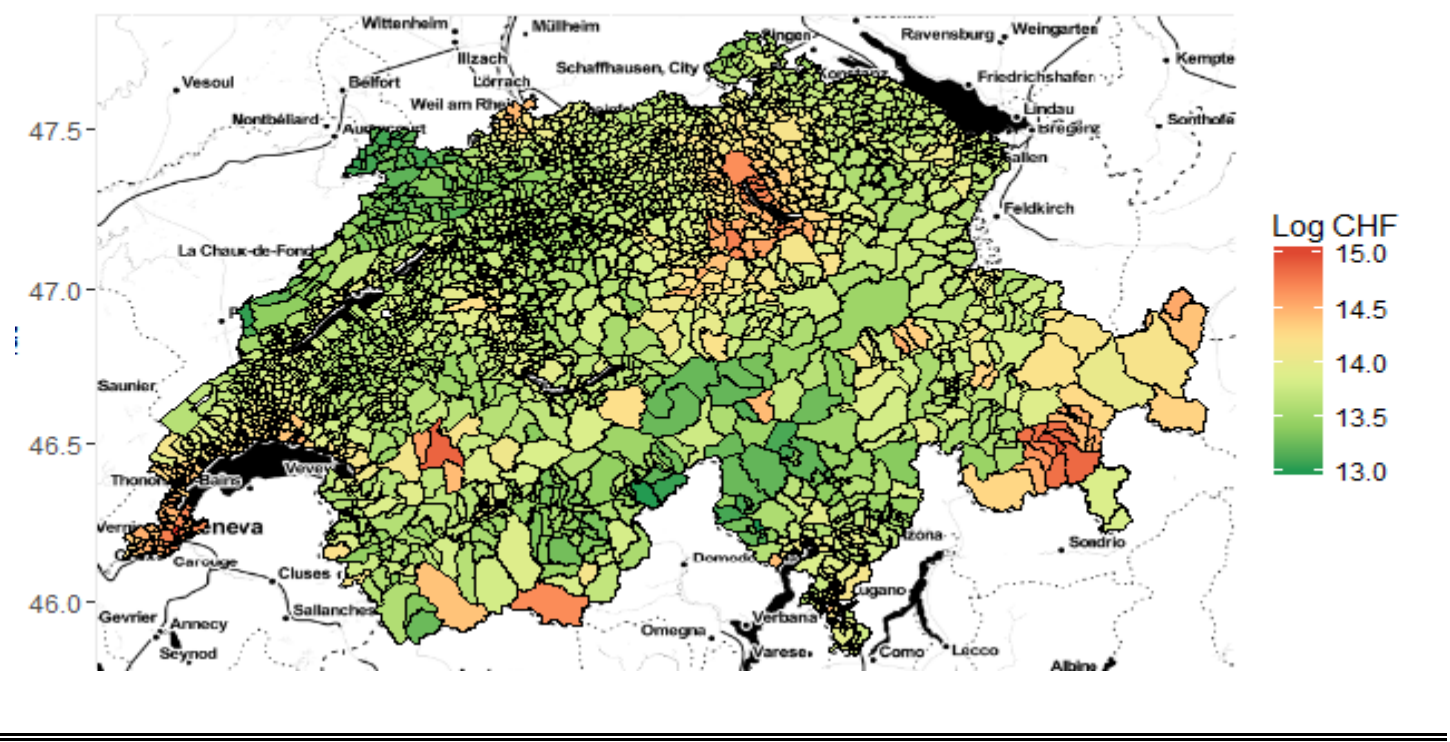




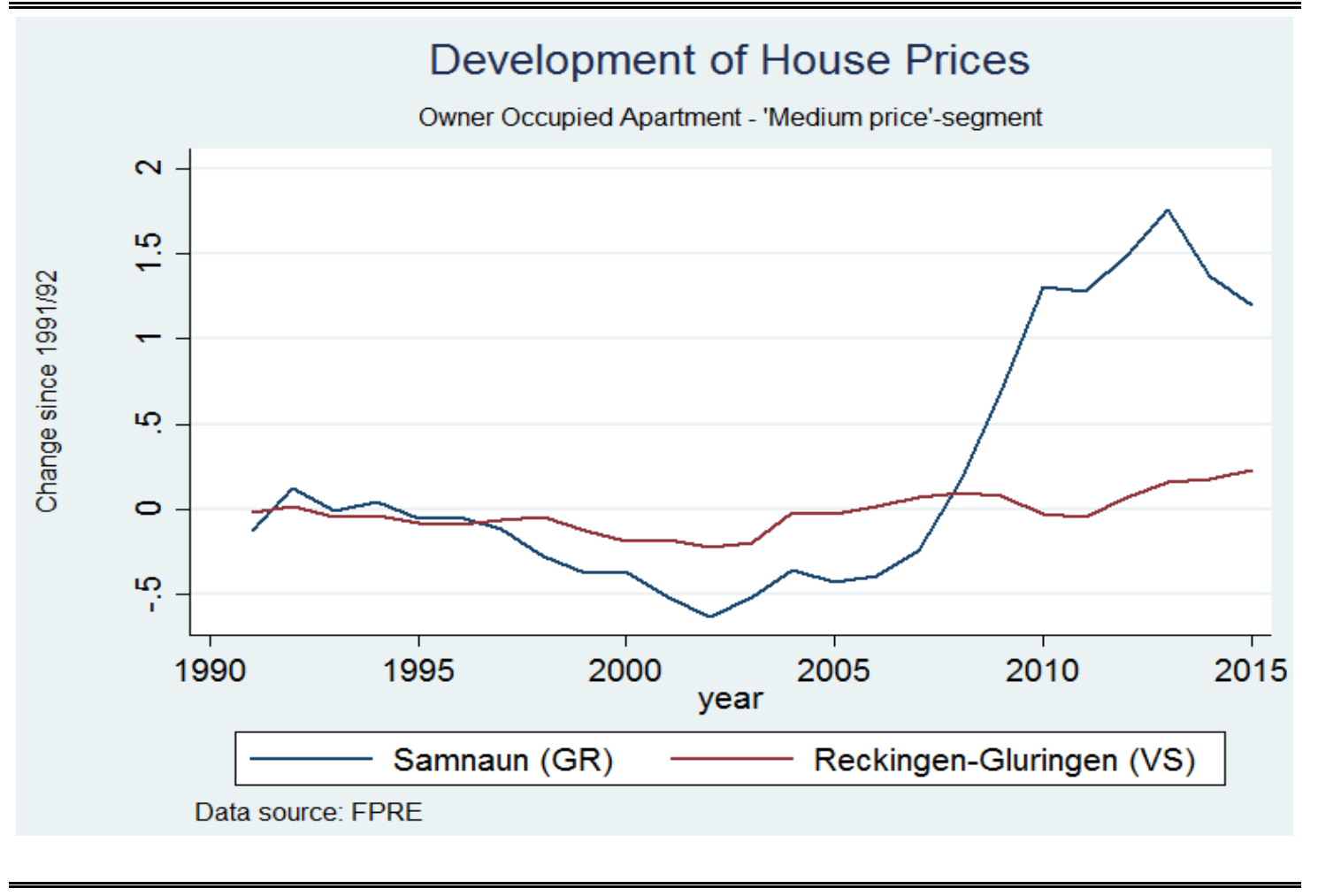


Panel A: Immigrants split by age

\begin{tabular}{l|rr:r} 
Age & Immigration & Emigration & Net Immigration \\
\hline Below 18 & 16,647 & 11,035 & 5,612 \\
Between 18 and 25 & 47,489 & 36,743 & 10,746 \\
Between 25 and 35 & 75,173 & 59,754 & 15,419 \\
Between 35 and 50 & 43,934 & 40,334 & 3,600 \\
Above 50 & 12,602 & 17,876 & $(5,274)$ \\
Total & 195,845 & 165,742 & 30,103
\end{tabular}

Panel B: Immigrants split by country of origin

\begin{tabular}{l|rr:r} 
Country of origin & Immigration & Emigration & Net Immigration \\
\hline Austria & 9,331 & 8,138 & 1,193 \\
Former Yugoslavia & 10,328 & 4,818 & 5,510 \\
France & 16,585 & 14,020 & 2,565 \\
Germany & 34,285 & 25,956 & 8,329 \\
Italy & 19,476 & 21,568 & $(2,092)$ \\
Portugal & 33,248 & 35,117 & $(1,869)$ \\
Spain & 4,327 & 7,731 & $(3,404)$ \\
Turkey & 2,705 & 1,673 & 1,032 \\
United Kingdom & 6,550 & 5,106 & 1,444 \\
United States & 3,974 & 3,513 & 461 \\
Rest of the World & 55,036 & 38,102 & 16,934 \\
Total & 195,845 & 165,742 & 30,103
\end{tabular}

Panel C: Immigrants split by residency permit

\begin{tabular}{l|rr:r} 
Residency permit & Immigration & Emigration & Net Immigration \\
\hline A- and L Permit & 82,453 & 77,396 & 5,057 \\
B-Permit (temporary residency) & 58,741 & 20,921 & 37,820 \\
C-Permit (long-term residency) & 4,062 & 23,885 & $(19,823)$ \\
Rest (i.e. temporary residents*) & 50,589 & 43,540 & 7,049 \\
Total & 195,845 & 165,742 & 30,103
\end{tabular}

*category includes refugees, asylum seekers and other "temporarily accepted/tolerated" migrants

The above table showcases how our data on immigration can be split. Panel A splits the data according to age of immigrants, Panel B by country of origin Panel $\mathrm{C}$ by the residency permits of immigrants 


\begin{tabular}{|c|c|c|c|c|c|c|}
\hline \multicolumn{7}{|l|}{ Panel A: Movement of households } \\
\hline \multirow[t]{2}{*}{ Characteristic } & \multicolumn{6}{|c|}{ Full sample } \\
\hline & $\mathrm{N}$ & mean & sd & $\mathrm{p} 50$ & $\min$ & $\max$ \\
\hline Household moves while in sample & 12,785 & 0.28 & 0.45 & 0 & 0 & 1 \\
\hline Household moves to a cheaper area & & & & & & \\
\hline while in sample & 12,785 & 0.07 & 0.26 & 0 & 0 & 1 \\
\hline $\begin{array}{l}\text { Household ever owns a home } \\
\text { Household ever buys home wh }\end{array}$ & 12,785 & 0.48 & 0.50 & 0 & 0 & 1 \\
\hline $\begin{array}{l}\text { Housenold ever buys home while } \\
\text { moving to a chearer area }\end{array}$ & 12785 & 002 & 014 & 0 & 0 & \\
\hline
\end{tabular}

\begin{tabular}{cccccc}
\multicolumn{8}{c}{ Households do not own when first observed } \\
\hline $\mathrm{N}$ & mean & sd & $\mathrm{p} 50$ & $\min$ & $\max$ \\
7,779 & 0.38 & 0.49 & 0 & 0 & 1 \\
7,779 & 0.10 & 0.30 & 0 & 0 & 1 \\
7,779 & 0.14 & 0.35 & 0 & 0 & 1 \\
7,779 & 0.03 & 0.17 & 0 & 0 & 1
\end{tabular}

Panel B: Movement differenced by price appreciation in a region

Area with strong price Area with less price

appreciation appreciation

Difference

Panel A in the above table shows how households in our sample move. The table represents cross sectional information; i.e. whether a household ever moves while in our sample.

We show this information separately for households that own a home when first observed and those that do not.

Panel B differences households that do not own at first observation by whether they are first observed in a region that experiences high price growth or not. 


\section{Panel A: Summary statistics}

\begin{tabular}{l|rrrrrrc} 
& \multicolumn{3}{|c}{} & & & & \\
& N & \multicolumn{2}{|c}{ mean } & sd & median & min & max \\
\hline Age of primary respodent & 73,726 & 51.3 & 15.9 & 50 & 15 & 103 \\
Years of eductaion (Household average) & 73,935 & 12.9 & 3.5 & 12 & 0 & 21 \\
Married/living together & 73,935 & 0.6 & 0.5 & 1 & 0 & 1 \\
Average income (in 100 000 CHF) & 73,935 & 1.0 & 0.9 & 0.8 & 0 & 61.9 \\
Number of children & 73,935 & 0.5 & 1.0 & 0 & 0 & 9 \\
Household is of Swiss Origin & 70,069 & 0.6 & 0.5 & 1 & 0 & 1 \\
Household political stance (10=right-wing)* & 68,256 & 4.8 & 1.7 & 4.3 & 0 & 10
\end{tabular}

\section{Panel B: Differenced by whether household moves}

Household moves while Household does not

move while in sample Difference

$\begin{array}{rrr}45.4 & 55.2 & -9.8^{* * *} \\ 13.5 & 12.5 & 1.0^{* * *} \\ 0.6 & 0.6 & 0.0^{* * *} \\ 1.0 & 0.9 & 0.1 * * * \\ 0.6 & 0.5 & 0.1 * * * \\ 0.6 & 0.7 & -0.1 * * * \\ 4.6 & 4.9 & -0.2 * * *\end{array}$

*used in some specifications

This table shows summary statistics for confounding variables. Panel B differences these by whether a household moves wile in the sample.

Avberage income is reported as annual income of the household $/ 100000$. In the case of gaps between years ( $5 \%$ of observations), values were imputed linearly.

Age of primary respondent is calculated as the age of the party in a household that first responded to the survey. The party responding can change.

Our results hold if we instead use average hh age. 


\begin{tabular}{|c|c|c|c|c|c|c|}
\hline The household ... & Number of observations & Mean (entire sample) & Standard Deviation & Median & $\begin{array}{c}\text { Min. } \\
\text { Value }\end{array}$ & $\begin{array}{c}\text { Max } \\
\text { Value } \\
\end{array}$ \\
\hline Has a car & 73,935 & 0.83 & 0.37 & 1 & 0 & 1 \\
\hline Has a dishwasher & 73,935 & 0.73 & 0.45 & 1 & 0 & 1 \\
\hline Has a computer & 73,935 & 0.78 & 0.42 & 1 & 0 & 1 \\
\hline Goes on vacations of $>1$ week & 70,528 & 0.78 & 0.41 & 1 & 0 & 1 \\
\hline Goes to the dentist regularly & 73,935 & 0.94 & 0.23 & 1 & 0 & 1 \\
\hline Has a washing machine & 73,935 & 0.66 & 0.47 & 1 & 0 & 1 \\
\hline Has a colour TV & 69,125 & 0.91 & 0.28 & 1 & 0 & 1 \\
\hline Is able to save for the 3rd pillar & 73,935 & 0.10 & 0.30 & 0 & 0 & 1 \\
\hline Index of consumption & 60,316 & 2.33 & 0.84 & 2 & 0 & 4 \\
\hline Consumable income & 57,940 & 0.78 & 0.12 & 0.8 & 0 & 1 \\
\hline
\end{tabular}

The above table depicts various consumption measures (first half of the table) as well as different household characteristics. Information is based on survey responses by 13,000 individual households. 


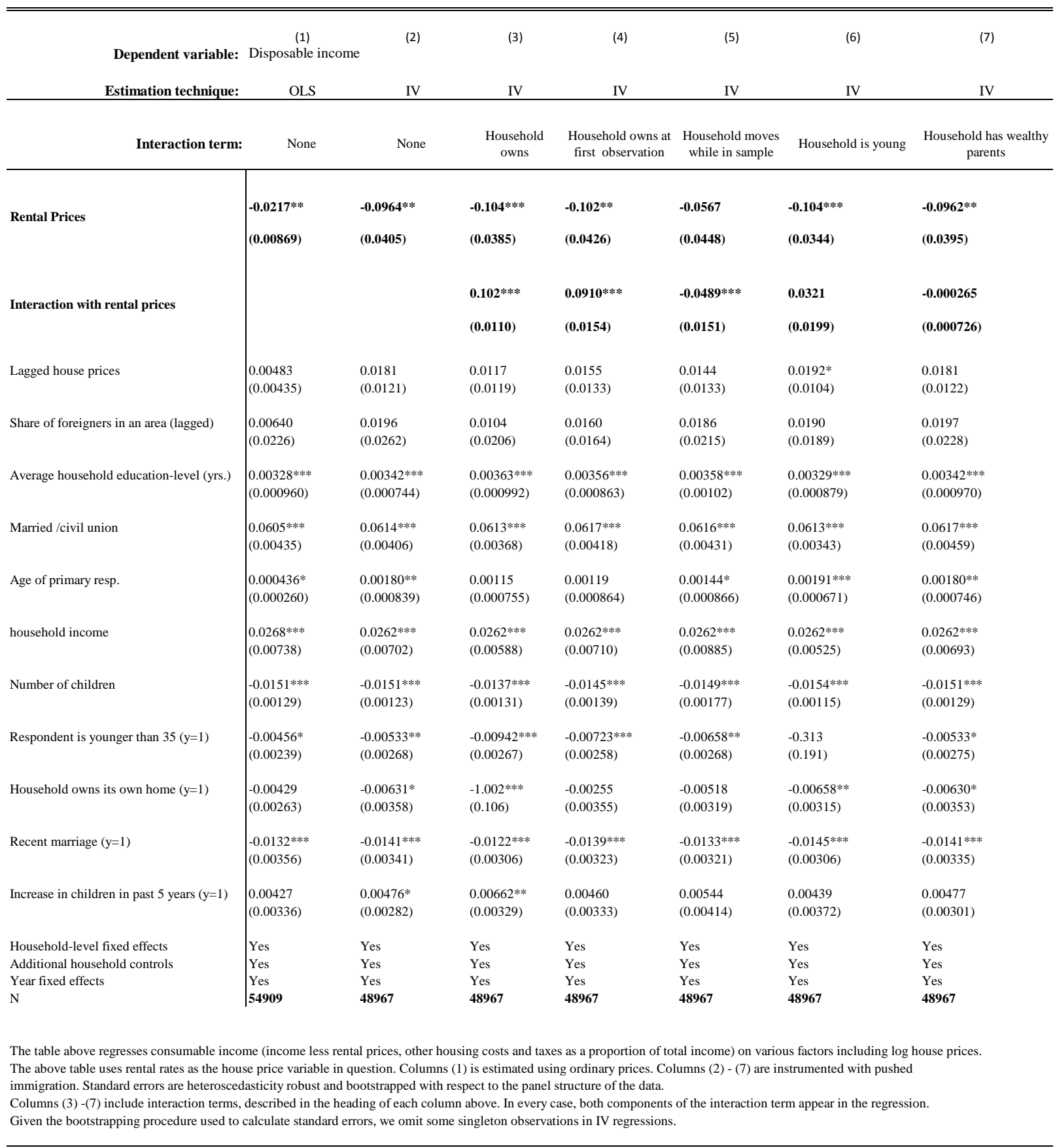




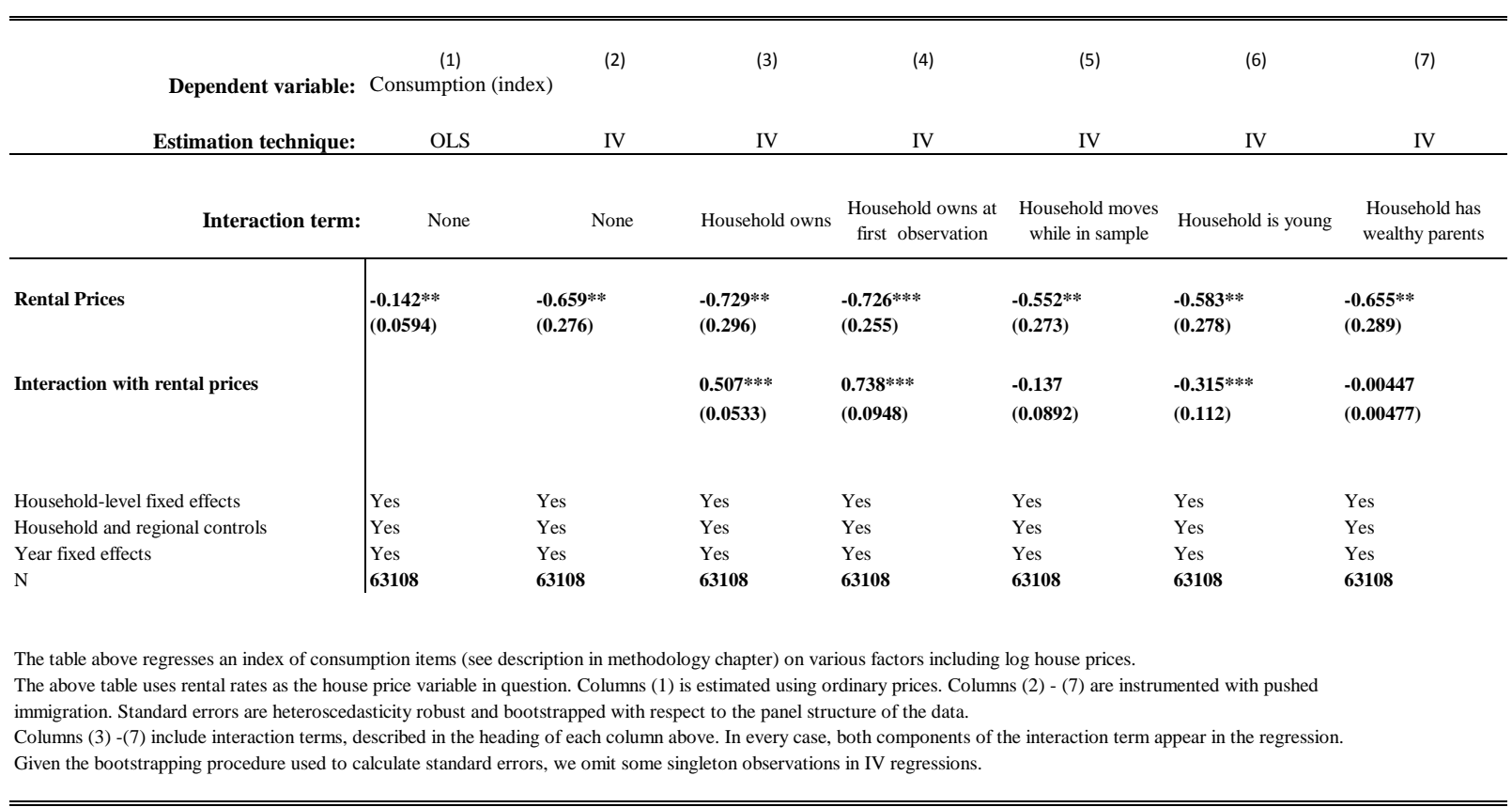


Dependent variable: Household transitions to ownership in following year

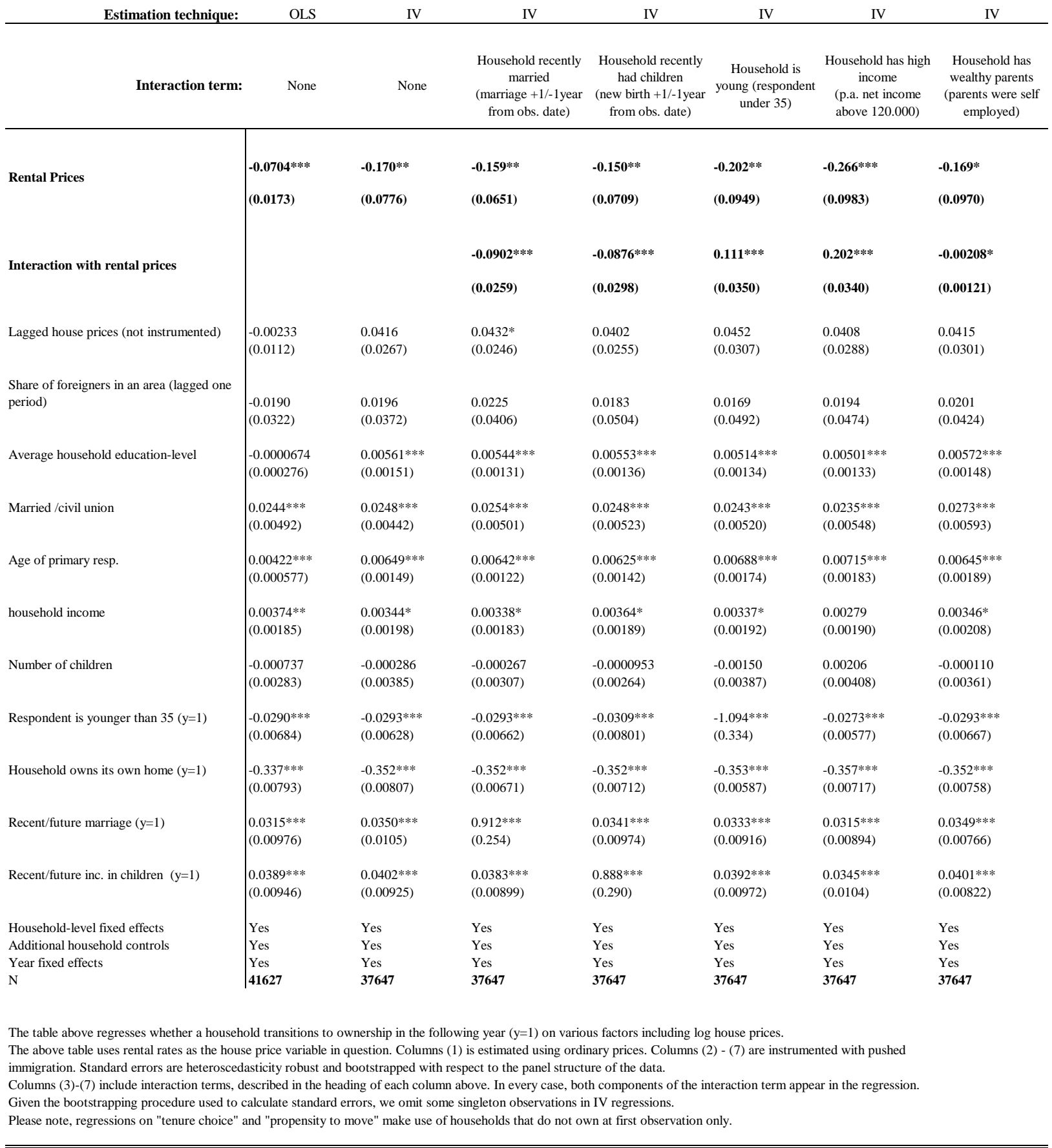




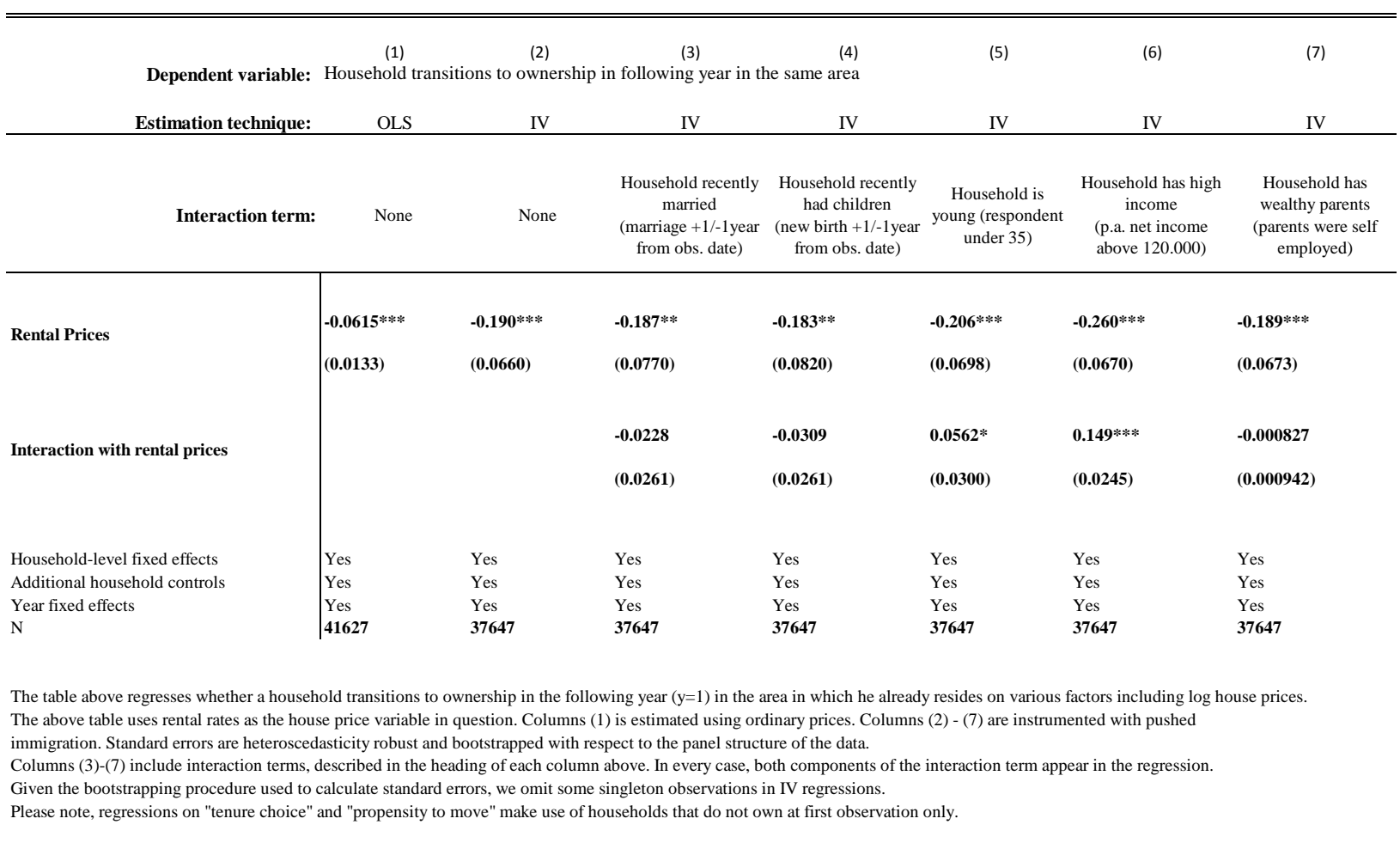




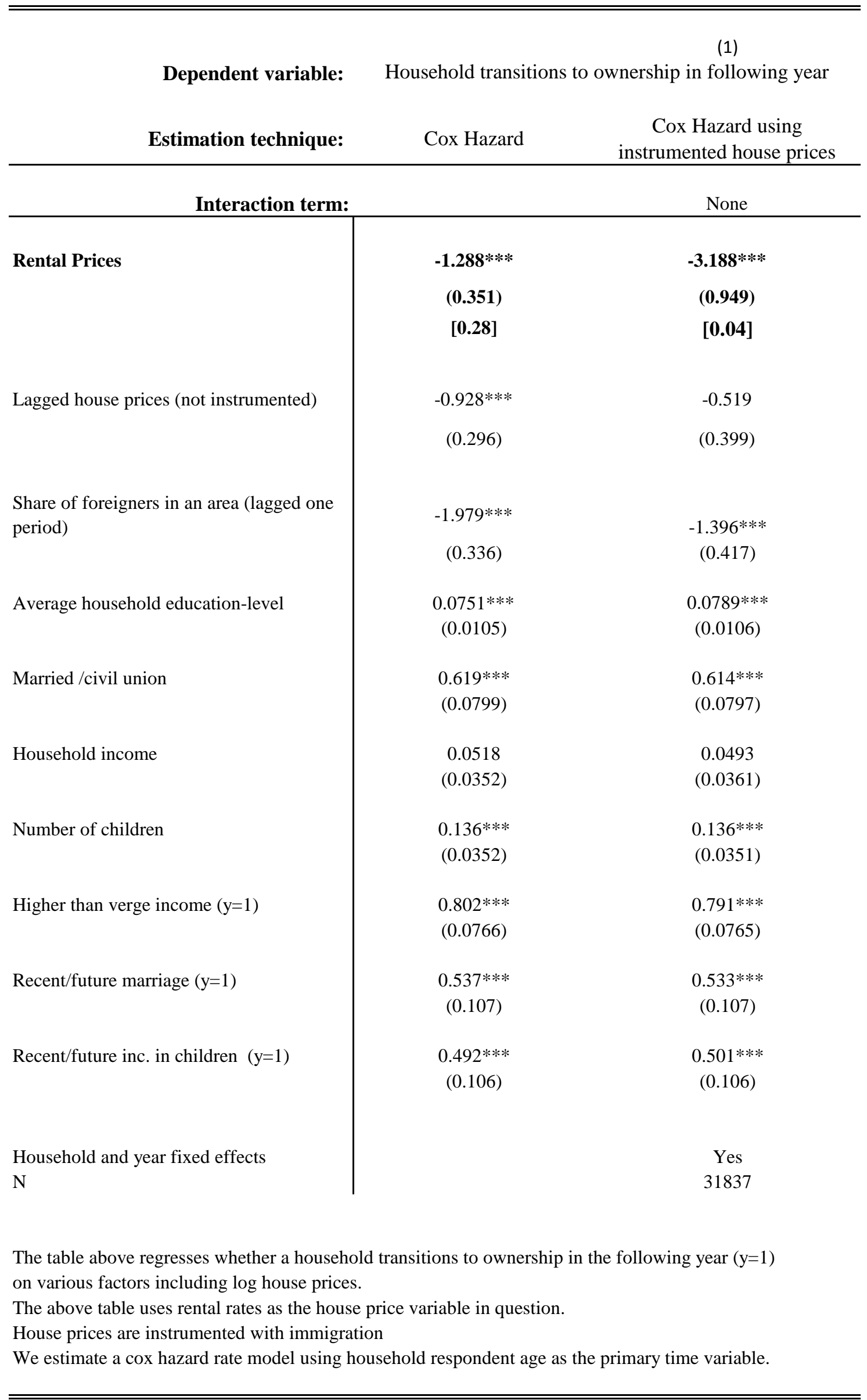



(3) (5) (6) Dependent variable: Household moves to a cheaper area OLS IV IV IV IV

\begin{tabular}{|c|c|c|c|c|c|c|c|}
\hline Interaction term & None & None & $\begin{array}{l}\text { Household recently } \\
\text { married } \\
\text { (marriage }+1 / \text {-1year } \\
\text { from obs. date) }\end{array}$ & $\begin{array}{l}\text { Household recently } \\
\text { had children } \\
\text { (new birth +1/-1year } \\
\text { from obs. date) }\end{array}$ & $\begin{array}{l}\text { Household is } \\
\text { young (respondent } \\
\text { under 35) }\end{array}$ & $\begin{array}{l}\text { Household has high } \\
\text { income } \\
\text { (p.a. net income } \\
\text { above 120.000) }\end{array}$ & $\begin{array}{c}\text { Household has } \\
\text { wealthy parents } \\
\text { (parents were self } \\
\text { employed) }\end{array}$ \\
\hline Rental Prices & $\begin{array}{l}0.249 * * * \\
(0.0149)\end{array}$ & $\begin{array}{l}0.851^{* * *} \\
(0.0983)\end{array}$ & $\begin{array}{l}0.855 * * * \\
(0.0933)\end{array}$ & $\begin{array}{l}0.852 * * * \\
(0.108)\end{array}$ & $\begin{array}{l}0.820 * * * \\
(0.117)\end{array}$ & $\begin{array}{l}0.827 * * * \\
(0.0831)\end{array}$ & $\begin{array}{l}0.853^{* * *} \\
(0.123)\end{array}$ \\
\hline Interaction with rental prices & & & $\begin{array}{l}-0.0310 \\
(0.0242)\end{array}$ & $\begin{array}{l}-0.00231 \\
(0.0237)\end{array}$ & $\begin{array}{l}0.112 * * * \\
(0.0343)\end{array}$ & $\begin{array}{l}0.0503 * * \\
(0.0205)\end{array}$ & $\begin{array}{l}-0.00216 \\
(0.00153)\end{array}$ \\
\hline Lagged house prices (not instrumented) & $\begin{array}{l}-0.00587 \\
(0.00839)\end{array}$ & $\begin{array}{l}-0.160^{* * *} \\
(0.0316)\end{array}$ & $\begin{array}{l}-0.160 * * * \\
(0.0272)\end{array}$ & $\begin{array}{l}-0.160 * * * \\
(0.0325)\end{array}$ & $\begin{array}{l}-0.156 * * * \\
(0.0351)\end{array}$ & $\begin{array}{l}-0.160 * * * \\
(0.0277)\end{array}$ & $\begin{array}{l}-0.160^{* * *} \\
(0.0389)\end{array}$ \\
\hline $\begin{array}{l}\text { Share of foreigners in an area (lagged one } \\
\text { period) }\end{array}$ & $\begin{array}{l}0.347 * * * \\
(0.0471)\end{array}$ & $\begin{array}{l}0.208^{* * *} \\
(0.0603)\end{array}$ & $\begin{array}{l}0.209 * * * \\
(0.0689)\end{array}$ & $\begin{array}{l}0.208 * * * \\
(0.0567)\end{array}$ & $\begin{array}{l}0.205 * * * \\
(0.0632)\end{array}$ & $\begin{array}{l}0.208 * * * \\
(0.0560)\end{array}$ & $\begin{array}{l}0.208 * * * \\
(0.0673)\end{array}$ \\
\hline Average household education-level & $\begin{array}{l}-0.000784 * * \\
(0.000318)\end{array}$ & $\begin{array}{l}0.00269^{* *} \\
(0.00114)\end{array}$ & $\begin{array}{l}0.00264^{* *} \\
(0.00119)\end{array}$ & $\begin{array}{l}0.00269 * * \\
(0.00137)\end{array}$ & $\begin{array}{l}0.00223 * \\
(0.00132)\end{array}$ & $\begin{array}{l}0.00255^{*} \\
(0.00133)\end{array}$ & $\begin{array}{l}0.00281 * * \\
(0.00140)\end{array}$ \\
\hline Married /civil union & $\begin{array}{l}-0.0155^{* * *} \\
(0.00467)\end{array}$ & $\begin{array}{l}-0.0143^{* *} \\
(0.00568)\end{array}$ & $\begin{array}{l}-0.0142^{* * *} \\
(0.00442)\end{array}$ & $\begin{array}{l}-0.0143^{* *} \\
(0.00615)\end{array}$ & $\begin{array}{l}-0.0148^{* * *} \\
(0.00551)\end{array}$ & $\begin{array}{l}-0.0147^{* * *} \\
(0.00499)\end{array}$ & $\begin{array}{l}-0.0118^{* *} \\
(0.00504)\end{array}$ \\
\hline Age of primary resp. & $\begin{array}{l}-0.00653 * * * \\
(0.000483)\end{array}$ & $\begin{array}{l}-0.0167 * * * \\
(0.00181)\end{array}$ & $\begin{array}{l}-0.0167 * * * \\
(0.00183)\end{array}$ & $\begin{array}{l}-0.0167 * * * \\
(0.00209)\end{array}$ & $\begin{array}{l}-0.0163 * * * \\
(0.00218)\end{array}$ & $\begin{array}{l}-0.0165 * * * \\
(0.00157)\end{array}$ & $\begin{array}{l}-0.0167 * * * \\
(0.00232)\end{array}$ \\
\hline household income & $\begin{array}{l}0.000789 \\
(0.00116)\end{array}$ & $\begin{array}{l}0.000643 \\
(0.00126)\end{array}$ & $\begin{array}{l}0.000622 \\
(0.00158)\end{array}$ & $\begin{array}{l}0.000648 \\
(0.00135)\end{array}$ & $\begin{array}{l}0.000577 \\
(0.00151)\end{array}$ & $\begin{array}{l}0.000482 \\
(0.00166)\end{array}$ & $\begin{array}{l}0.000663 \\
(0.00143)\end{array}$ \\
\hline Number of children & $\begin{array}{l}-0.00489 * * \\
(0.00224)\end{array}$ & $\begin{array}{l}-0.00522^{* *} \\
(0.00239)\end{array}$ & $\begin{array}{l}-0.00522 * * \\
(0.00250)\end{array}$ & $\begin{array}{l}-0.00522 * * \\
(0.00210)\end{array}$ & $\begin{array}{l}-0.00645^{* * *} \\
(0.00213)\end{array}$ & $\begin{array}{l}-0.00464 * \\
(0.00239)\end{array}$ & $\begin{array}{l}-0.00504^{*} \\
(0.00270)\end{array}$ \\
\hline Respondent is younger than $35(\mathrm{y}=1)$ & $\begin{array}{l}-0.00679 \\
(0.00539)\end{array}$ & $\begin{array}{l}-0.00417 \\
(0.00487)\end{array}$ & $\begin{array}{l}-0.00416 \\
(0.00441)\end{array}$ & $\begin{array}{l}-0.00422 \\
(0.00471)\end{array}$ & $\begin{array}{l}-1.079 * * * \\
(0.329)\end{array}$ & $\begin{array}{l}-0.00366 \\
(0.00429)\end{array}$ & $\begin{array}{l}-0.00416 \\
(0.00525)\end{array}$ \\
\hline Household owns its own home $(y=1)$ & $\begin{array}{l}-0.0462^{* * * *} \\
(0.00569)\end{array}$ & $\begin{array}{l}-0.0439 * * * \\
(0.00547)\end{array}$ & $\begin{array}{l}-0.0439 * * * \\
(0.00518)\end{array}$ & $\begin{array}{l}-0.0439 * * * \\
(0.00516)\end{array}$ & $\begin{array}{l}-0.0450^{* * *} \\
(0.00555)\end{array}$ & $\begin{array}{l}-0.0451^{* * *} \\
(0.00548)\end{array}$ & $\begin{array}{l}-0.0439 * * * \\
(0.00570)\end{array}$ \\
\hline Recent/future marriage (y=1) & $\begin{array}{l}0.00439 \\
(0.00646)\end{array}$ & $\begin{array}{l}0.00670 \\
(0.00745)\end{array}$ & $\begin{array}{l}0.308 \\
(0.236)\end{array}$ & $\begin{array}{l}0.00668 \\
(0.00775)\end{array}$ & $\begin{array}{l}0.00502 \\
(0.00750)\end{array}$ & $\begin{array}{l}0.00583 \\
(0.00784)\end{array}$ & $\begin{array}{l}0.00659 \\
(0.00706)\end{array}$ \\
\hline Recent/future inc. in children $(y=1)$ & $\begin{array}{l}-0.00938 \\
(0.00597)\end{array}$ & $\begin{array}{l}-0.0125 \\
(0.00782)\end{array}$ & $\begin{array}{l}-0.0132 * \\
(0.00777)\end{array}$ & $\begin{array}{l}0.00986 \\
(0.229)\end{array}$ & $\begin{array}{l}-0.0135 * \\
(0.00764)\end{array}$ & $\begin{array}{l}-0.0139 * \\
(0.00825)\end{array}$ & $\begin{array}{l}-0.0126 \\
(0.00841)\end{array}$ \\
\hline $\begin{array}{l}\text { Household-level fixed effects } \\
\text { Additional household controls } \\
\text { Year fixed effects } \\
\text { N }\end{array}$ & $\begin{array}{l}\text { Yes } \\
\text { Yes } \\
\text { Yes } \\
\mathbf{4 1 6 2 7}\end{array}$ & $\begin{array}{l}\text { Yes } \\
\text { Yes } \\
\text { Yes } \\
\mathbf{3 7 6 4 7}\end{array}$ & $\begin{array}{l}\text { Yes } \\
\text { Yes } \\
\text { Yes } \\
\mathbf{3 7 6 4 7}\end{array}$ & $\begin{array}{l}\text { Yes } \\
\text { Yes } \\
\text { Yes } \\
\mathbf{3 7 6 4 7}\end{array}$ & $\begin{array}{l}\text { Yes } \\
\text { Yes } \\
\text { Yes } \\
\mathbf{3 7 6 4 7}\end{array}$ & $\begin{array}{l}\text { Yes } \\
\text { Yes } \\
\text { Yes } \\
\mathbf{3 7 6 4 7}\end{array}$ & $\begin{array}{l}\text { Yes } \\
\text { Yes } \\
\text { Yes } \\
\mathbf{3 7 6 4 7}\end{array}$ \\
\hline $\begin{array}{l}\text { The table above regresses whether a house } \\
\text { The above table uses rental rates as the hol } \\
\text { immigration. Standard errors are heterosce } \\
\text { Columns (3)-(7) include interaction terms, } \\
\text { Given the bootstrapping procedure used to } \\
\text { Please note, regressions on "tenure choice" }\end{array}$ & $\begin{array}{l}\text { old moves awa } \\
\text { se price variable } \\
\text { lasticity robust } \\
\text { lescribed in the } \\
\text { calculate standa } \\
\text { and "propensity }\end{array}$ & $\begin{array}{l}n \text { area that is cl } \\
\text { lestion. Colum } \\
\text { ootstrapped wi } \\
\text { ng of each colv } \\
\text { ors, we omit s } \\
\text { ove" make use }\end{array}$ & $\begin{array}{l}\text { than the one in which } \\
\text { is estimated using ordi } \\
\text { pect to the panel struct } \\
\text { oove. In every case, bo } \\
\text { ingleton observations il } \\
\text { useholds that do not ov }\end{array}$ & $\begin{array}{l}\text { it is observed }(y=1) \text { on } \\
\text { inary prices. Columns ( } 2 \\
\text { ure of the data. } \\
\text { th components of the int } \\
n \text { IV regressions. } \\
\text { wn at first observation ol }\end{array}$ & $\begin{array}{l}\text { various factors inclu } \\
\text { 2) - (7) are instrumen } \\
\text { teraction term appea } \\
\text { only. }\end{array}$ & $\begin{array}{l}\text { uding log house price } \\
\text { nted with pushed } \\
\text { ar in the regression. }\end{array}$ & \\
\hline
\end{tabular}


Dependent variable: Log of single family house prices

(3)

Estimation technique:

\begin{tabular}{|c|c|c|c|}
\hline Net Immigration (total) & $\begin{array}{l}1.26 * * * \\
(0.0475)\end{array}$ & - & - \\
\hline Net Immigration Germany & - & $\begin{array}{l}0.16^{*} \\
(0.0868)\end{array}$ & $\begin{array}{l}-0.06 \\
(0.0856)\end{array}$ \\
\hline Net Immigration former Yugoslavia & - & $\begin{array}{l}-0.33 \\
(0.2901)\end{array}$ & $\begin{array}{l}-0.34 \\
(0.2858)\end{array}$ \\
\hline Net Immigration France & - & - & $\begin{array}{l}7.05^{* * *} \\
(0.1961)\end{array}$ \\
\hline Net Immigration Spain & - & - & $\begin{array}{l}9.37^{* * *} \\
(0.5761)\end{array}$ \\
\hline Net Immigration Portugal & - & - & $\begin{array}{l}3.49 * * * \\
(0.1986)\end{array}$ \\
\hline Net Immigration US & - & - & $\begin{array}{l}1.45^{* * *} \\
(0.1585)\end{array}$ \\
\hline Net Immigration UK & - & - & $\begin{array}{l}5.83 * * * \\
(0.3123)\end{array}$ \\
\hline Net Immigration Italy & - & - & $\begin{array}{l}-0.78^{* * *} \\
(0.0986)\end{array}$ \\
\hline Net Immigration Austria & - & - & $\begin{array}{l}0.1 \\
(0.1461)\end{array}$ \\
\hline Net Immigration Turkey & - & - & $\begin{array}{l}-0.87 \\
(1.0513)\end{array}$ \\
\hline Net Immigration Rest of World & - & $\begin{array}{l}1.82^{* * *} \\
(0.0594)\end{array}$ & $\begin{array}{l}4.46^{* * *} \\
(0.2415)\end{array}$ \\
\hline $\begin{array}{l}\text { Region and Year fixed effects } \\
\text { Additional region controls } \\
N\end{array}$ & $\begin{array}{l}\text { Yes } \\
\text { Yes } \\
51106\end{array}$ & $\begin{array}{l}\text { Yes } \\
\text { Yes } \\
51106\end{array}$ & $\begin{array}{l}\text { Yes } \\
\text { Yes } \\
51106\end{array}$ \\
\hline
\end{tabular}

The above regression relates log house prices to immigration.

We split immigration along various dimensions relating to immigrant "origin" We estimate our results using a SAR model. 
Dependent variable: Log of single family house prices

\begin{tabular}{|c|c|c|c|}
\hline Estimation technique: & & SAR & \\
\hline Spatial lag & $\begin{array}{l}0.82 * * * \\
(0.0028)\end{array}$ & $\begin{array}{l}0.82^{* * *} \\
(0.0028)\end{array}$ & $\begin{array}{l}0.81 * * * \\
(0.0029)\end{array}$ \\
\hline Net Immigration (total) & $\begin{array}{l}0.42^{*} \\
(0.0281)\end{array}$ & - & - \\
\hline Net Immigration Germany & - & $\begin{array}{l}0.2 * * * \\
(0.0514)\end{array}$ & $\begin{array}{l}0.1^{* * *} \\
(0.0516)\end{array}$ \\
\hline Net Immigration former Yugoslavia & - & $\begin{array}{l}-0.84^{* * *} \\
(0.1718)\end{array}$ & $\begin{array}{l}-0.9 * * * \\
(0.1725)\end{array}$ \\
\hline Net Immigration France & - & - & $\begin{array}{l}2.12^{* * *} \\
(0.1186)\end{array}$ \\
\hline Net Immigration Spain & - & - & $\begin{array}{l}1.17 * * * \\
(0.3477)\end{array}$ \\
\hline Net Immigration Portugal & - & - & $\begin{array}{l}1.55^{* * *} \\
(0.1199)\end{array}$ \\
\hline Net Immigration US & - & - & $\begin{array}{l}0.39 * * * \\
(0.0957)\end{array}$ \\
\hline Net Immigration UK & - & - & $\begin{array}{l}1.81 * * * \\
(0.1886)\end{array}$ \\
\hline Net Immigration Italy & - & - & $\begin{array}{c}-0.29 * * * \\
(0.0595)\end{array}$ \\
\hline Net Immigration Austria & - & - & $\begin{array}{l}0.14 \\
(0.0882)\end{array}$ \\
\hline Net Immigration Turkey & - & - & $\begin{array}{l}-0.27 \\
(0.6345)\end{array}$ \\
\hline Net Immigration Rest of World & - & $\begin{array}{l}0.55^{* * *} \\
(0.0352)\end{array}$ & $\begin{array}{l}1.58 * * * \\
(0.1458)\end{array}$ \\
\hline $\begin{array}{l}\text { Region and Year fixed effects } \\
\text { Additional region controls } \\
\mathrm{N}\end{array}$ & $\begin{array}{l}\text { Yes } \\
\text { Yes } \\
51106\end{array}$ & $\begin{array}{l}\text { Yes } \\
\text { Yes } \\
51106\end{array}$ & $\begin{array}{l}\text { Yes } \\
\text { Yes } \\
51106\end{array}$ \\
\hline
\end{tabular}

The above regression relates log house prices to immigration. We split immigration along various dimensions relating to immigrant "origin" We estimate our results using an SAR model. 
Dependent variable: Log of single family house prices

Estimation technique:

Immigrants with a medium-term residency permit (category B)

Immigrants with a long-term residency permit (category C)

Refugees, Asylum seekers and short term immigrants remaining for more than 1 year

Diplomats and all others

Region and Year fixed effects

Additional region controls

$\mathrm{N}$
OLS

$1.85 * * *$

(0.1464)

$4.31^{* * *}$

(0.2256)

$-0.07$

(0.0533)

$-0.06$

(0.053)

Yes

Yes

51106

The above regression relates log house prices to immigration.

We split immigration along various dimensions relating to the residency permit

We estimate our results using an OLS model. 
Table 14

(1)

Dependent variable: $\log$ of single family house prices

Estimation technique:

OLS

\section{Spatial lag}

Immigrants with a medium-term residency permit (category B)

$0.81 * * *$

(0.0029)

$1.16 * * *$

$(0.0863)$

Immigrants with a long-term residency permit (category C)

$1.41 * * *$

(0.133)

$-0.03^{*}$

Refugees, Asylum seekers and short term immigrants remaining for more than 1 year

Diplomats and all others

(0.0312)

Region and Year fixed effects

Additional region controls

Yes

Yes

51106

The above regression relates log house prices to immigration.

We split immigration along various dimensions relating to the residency permit

We estimate our results using a SAR model. 


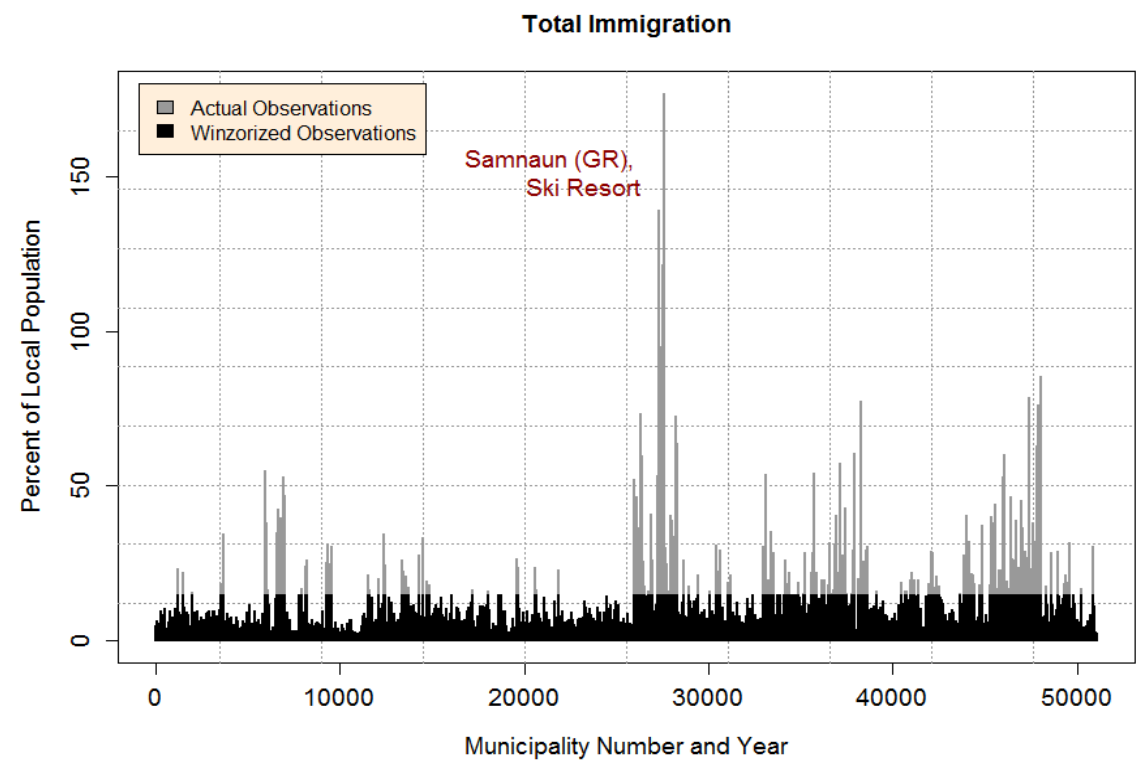

From 1992 to 2013, the Ski Resort of St. Moritz experienced a high degree of immigration from Italy and Portugal. The typical occupation for these immigrants is in the tourism sector related to the skiing activity. For instance, the average annual immigration from Italy was $29 \%$ of local population and the average annual immigration from Portugal was $23 \%$ of population.

The winzorizing sets a cap at $15 \%$ which affects $3.5 \%$ of the observations. The average immigration falls only mildly from $3.46 \%$ to $3.12 \%$. However, a few outliers are strongly affected by this change and the overall distribution of immigration is more homogeneous

Panel B

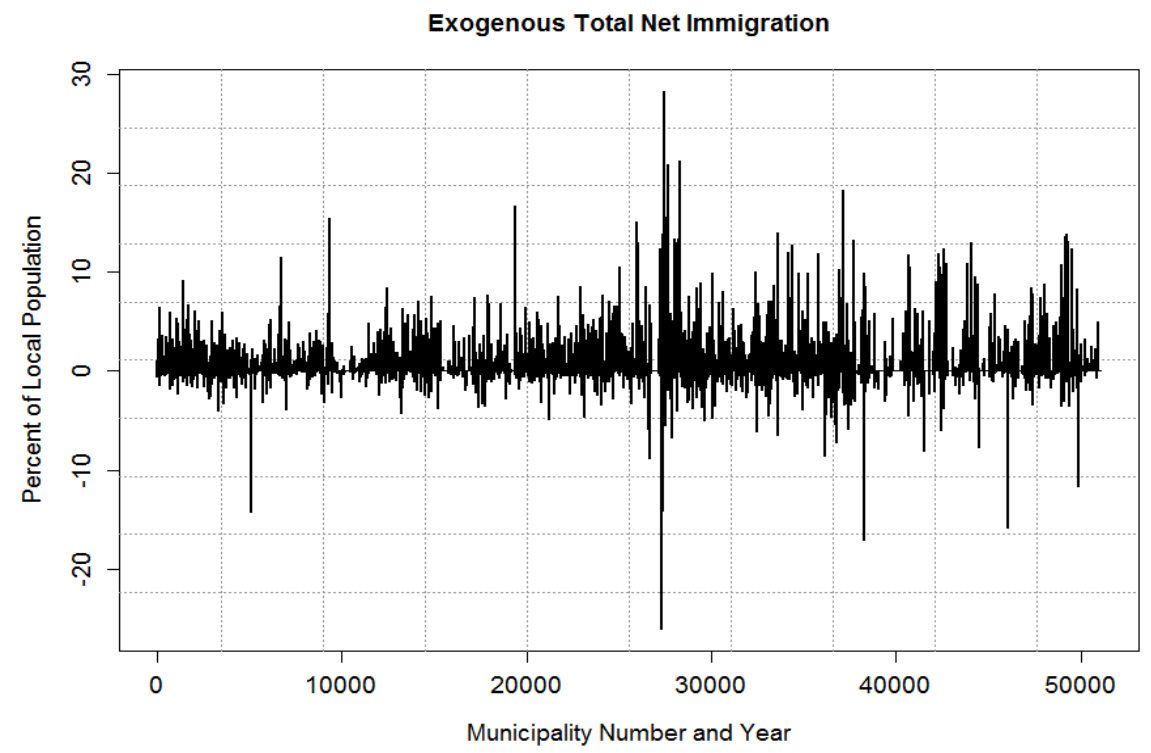


Appendix 1

\begin{tabular}{l|r}
\hline \hline & Net Immigration \\
Community Name & 3548 \\
\hline Zürich & 2294 \\
Genève & 1147 \\
Basel & 986 \\
Bern & 951 \\
St. Moritz & 888 \\
Lausanne & -91 \\
& -101 \\
Schafisheim & -166 \\
Peseux & -271 \\
Grindelwald & \\
Zermatt & \\
& \\
The above table depicts net immigration. It is \\
truncated to show only those regions with \\
the highest and lowest rates of net immigration. \\
\end{tabular}


(1)

Dependent variable: Disposable income (gross)

Estimation technique:

OLS

IV

(3)

(4)

IV

IV

IV

\begin{tabular}{|c|c|c|c|c|c|c|c|}
\hline Interaction term: & None & None & Household owns & $\begin{array}{l}\text { Household owns at } \\
\text { first observation }\end{array}$ & $\begin{array}{l}\text { Household moves } \\
\text { while in sample }\end{array}$ & Household is young & $\begin{array}{l}\text { Household has } \\
\text { wealthy parents }\end{array}$ \\
\hline House prices & $\begin{array}{l}-0.0289 * * * \\
(0.00699)\end{array}$ & $\begin{array}{l}-0.0883^{* * *} \\
(0.0287)\end{array}$ & $\begin{array}{l}-0.0957 * * * \\
(0.0286)\end{array}$ & $\begin{array}{l}-0.0934 * * * \\
(0.0287)\end{array}$ & $\begin{array}{l}-0.0569 * \\
(0.0297)\end{array}$ & $\begin{array}{l}-0.101 * * * \\
(0.0289)\end{array}$ & $\begin{array}{l}-0.0882 * * * \\
(0.0287)\end{array}$ \\
\hline Interaction with house prices & & & $\begin{array}{l}0.0931 * * * \\
(0.00637)\end{array}$ & $\begin{array}{l}0.0775 * * * \\
(0.0103)\end{array}$ & $\begin{array}{l}-0.0387 * * * \\
(0.00976)\end{array}$ & $\begin{array}{l}0.0518 * * * \\
(0.0144)\end{array}$ & $\begin{array}{l}-0.0000966 \\
(0.000413)\end{array}$ \\
\hline Household-level fixed effects & Yes & Yes & Yes & Yes & Yes & Yes & Yes \\
\hline Household and regional controls & Yes & Yes & Yes & Yes & Yes & Yes & Yes \\
\hline Year fixed effects & Yes & Yes & Yes & Yes & Yes & Yes & Yes \\
\hline $\mathrm{N}$ & 54708 & 48807 & 48807 & 48807 & 48807 & 48807 & 48807 \\
\hline
\end{tabular}

The table above regresses consumable income (gross income less rental prices and other housing costs as a proportion of total income) on various factors including log house prices. The above table uses the price of single family homes as a proxy for house prices. Columns (1) is estimated using ordinary prices. Columns (2) - (7) are instrumented with pushed The above table uses the price of single family homes as a proxy for house prices. Columns (1) is estimated using ordinary pic
immigration. Standard errors are heteroscedasticity robust and bootstrapped with respect to the panel structure of the data.

Columns (3) -(7) include interaction terms, described in the heading of each column above. In every case, both components of the interaction term appear in the regression. Given the bootstrapping procedure used to calculate standard errors, we omit some singleton observations in IV regressions.

$\underline{\underline{P a n e l ~ B}}$

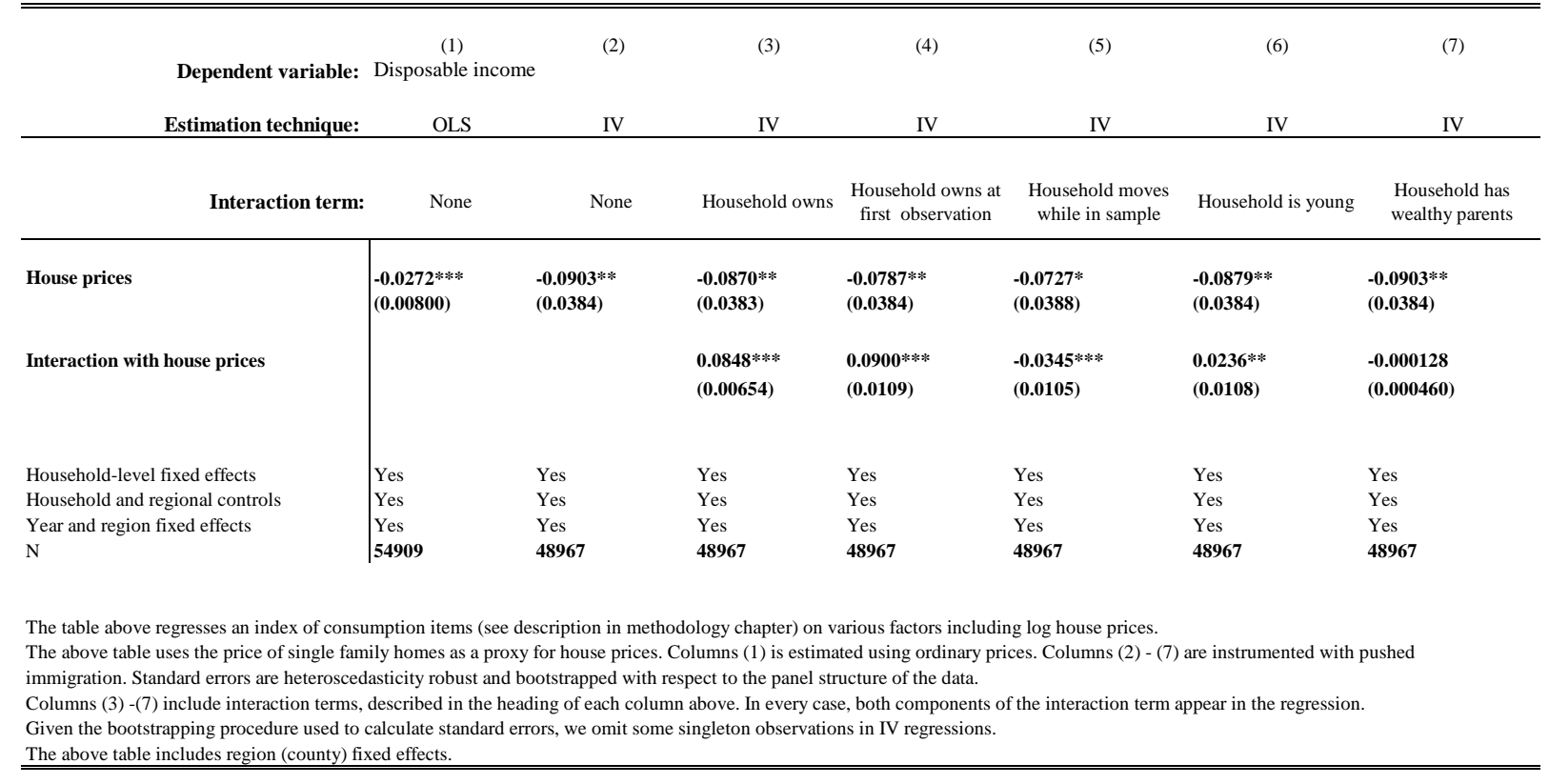


(1)

Dependent variable: Disposable income

(2)

(3)

(4)

(5)

(6)

(7)

Estimation technique:

OLS

IV

IV

IV

IV

\begin{tabular}{|c|c|c|c|c|c|c|c|}
\hline Interaction term: & None & None & $\begin{array}{l}\text { Household } \\
\text { owns }\end{array}$ & $\begin{array}{l}\text { Household owns at } \\
\text { first observation }\end{array}$ & $\begin{array}{l}\text { Household moves } \\
\text { while in sample }\end{array}$ & Household is young & $\begin{array}{l}\text { Household has } \\
\text { wealthy parents }\end{array}$ \\
\hline House prices & $\begin{array}{l}-0.0181 * * * \\
(0.00579)\end{array}$ & $\begin{array}{l}-0.0511^{* * * *} \\
(0.0188)\end{array}$ & $\begin{array}{l}-0.0530 * * * \\
(0.0196)\end{array}$ & $\begin{array}{l}-0.0519 * * * \\
(0.0150)\end{array}$ & $\begin{array}{l}-0.0327 * \\
(0.0176)\end{array}$ & $\begin{array}{l}-0.0552^{* * *} \\
(0.0199)\end{array}$ & $\begin{array}{l}-0.0511 * * * \\
(0.0184)\end{array}$ \\
\hline Interaction with house prices & & & $\begin{array}{l}0.0547 * * * \\
(0.00586)\end{array}$ & $\begin{array}{l}0.0439 * * * \\
(0.00711)\end{array}$ & $\begin{array}{l}-0.0248^{* * *} \\
(0.00756)\end{array}$ & $\begin{array}{l}0.0182 * \\
(0.0107)\end{array}$ & $\begin{array}{l}-0.000209 \\
(0.000518)\end{array}$ \\
\hline Household-level fixed effects & Yes & Yes & Yes & Yes & Yes & Yes & Yes \\
\hline Household and regional controls & Yes & Yes & Yes & Yes & Yes & Yes & Yes \\
\hline Year fixed effects & Yes & Yes & Yes & Yes & Yes & Yes & Yes \\
\hline $\mathrm{N}$ & 54909 & 48967 & 48967 & 48967 & 48967 & 48967 & 48967 \\
\hline
\end{tabular}

The table above regresses consumable income (income less rental prices and other housing costs and taxes as a proportion of total income) on various factors including log house prices. House prices are log (single family home prices) as opposed to $\log ($ rental rates). Columns (1) is estimated using ordinary prices. Columns (2) - (7) are instrumented with pushed immigration. Standard errors are heteroscedasticity robust and bootstrapped with respect to the panel structure of the data.

Columns (3) -(7) include interaction terms, described in the heading of each column above. In every case, both components of the interaction term appear in the regression. Given the bootstrapping procedure used to calculate standard errors, we omit some singleton observations in IV regressions.

$\underline{\underline{P a n e l ~ B}}$

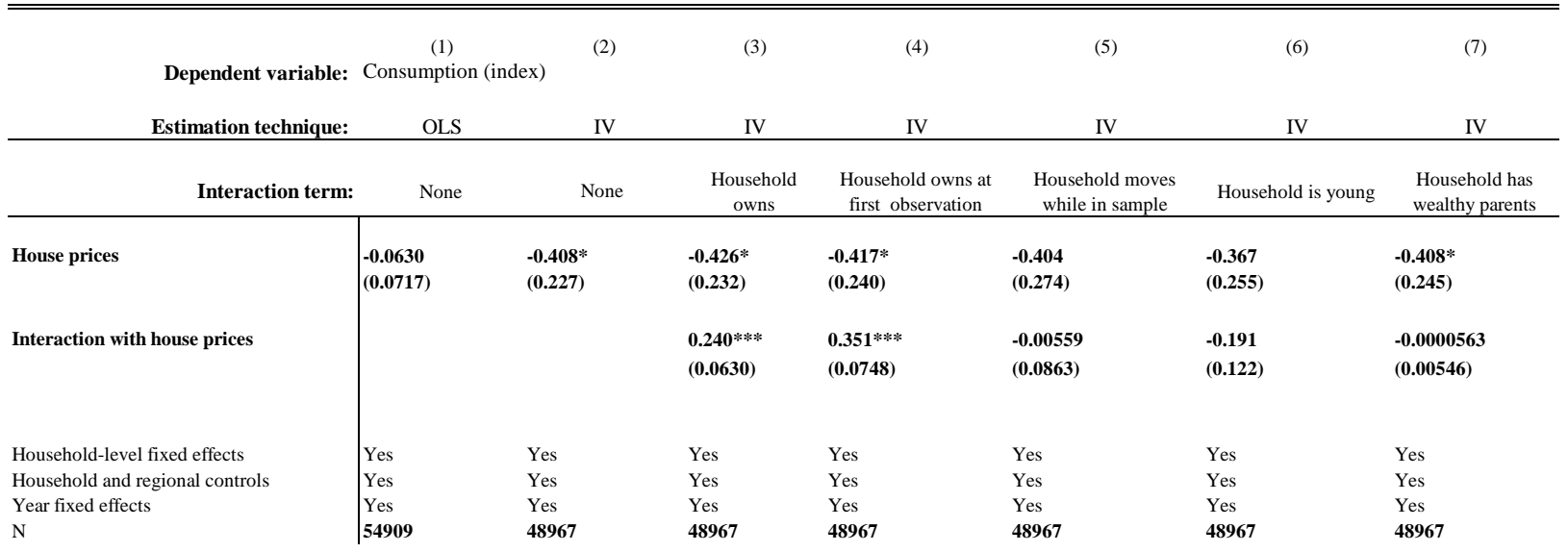

The table above regresses an index of consumption items (see description in methodology chapter) on various factors including log house prices.

House prices are log (single family home prices) as opposed to $\log ($ rental rates). Columns (1) is estimated using ordinary prices. Columns (2) - (7) are instrumented with pushed immigration. Standard errors are heteroscedasticity robust and bootstrapped with respect to the panel structure of the data.

Columns (3) -(7) include interaction terms, described in the heading of each column above. In every case, both components of the interaction term appear in the regression.

Given the bootstrapping procedure used to calculate standard errors, we omit some singleton observations in IV regressions. 
Panel A

(2)

(3)

(4)

(5)

(6)

Dependent variable: Household transitions to ownership in following year

\begin{tabular}{|c|c|c|c|c|c|c|c|}
\hline Estimation technique: & OLS & IV & IV & IV & IV & IV & IV \\
\hline Interaction term: & None & None & $\begin{array}{l}\text { Household recently } \\
\text { married }\end{array}$ & $\begin{array}{l}\text { Household recently } \\
\text { had children }\end{array}$ & Household is young & $\begin{array}{l}\text { Household has high } \\
\text { income }\end{array}$ & $\begin{array}{l}\text { Household has } \\
\text { wealthy parents }\end{array}$ \\
\hline House prices & $\begin{array}{l}-0.0451 * * * \\
(0.00987)\end{array}$ & $\begin{array}{l}-0.0705 * * \\
(0.0339)\end{array}$ & $\begin{array}{l}-0.0660^{* *} \\
(0.0311)\end{array}$ & $\begin{array}{l}-0.0621 * \\
(0.0361)\end{array}$ & $\begin{array}{l}-0.0873 * * \\
(0.0370)\end{array}$ & $\begin{array}{l}-0.119 * * * \\
(0.0338)\end{array}$ & $\begin{array}{l}-0.0698^{*} \\
(0.0375)\end{array}$ \\
\hline Interaction with house prices & & & $\begin{array}{l}-0.0408 * * \\
(0.0165)\end{array}$ & $\begin{array}{l}-0.0387^{* *} \\
(0.0156)\end{array}$ & $\begin{array}{l}0.0657^{* * *} \\
(0.0221)\end{array}$ & $\begin{array}{l}0.107^{* * *} \\
(0.0177)\end{array}$ & $\begin{array}{l}-0.00153 * * \\
(0.000725)\end{array}$ \\
\hline Household-level fixed effects & Yes & Yes & Yes & Yes & Yes & Yes & Yes \\
\hline Additional household controls & Yes & Yes & Yes & Yes & Yes & Yes & Yes \\
\hline Year fixed effects & Yes & Yes & Yes & Yes & Yes & Yes & Yes \\
\hline $\mathrm{N}$ & 41627 & 37647 & 37647 & 37647 & 37647 & 37647 & 37647 \\
\hline
\end{tabular}

The table above regresses whether a household transitions to ownership in the following year $(\mathrm{y}=1)$ on various factors including log house prices.

House prices are $\log$ (single family home prices) as opposed to $\log ($ rental rates). Columns (1) is estimated using ordinary prices. Columns (2) - (7) are instrumented with pushed

immigration. Standard errors are heteroscedasticity robust and bootstrapped with respect to the panel structure of the data.

Columns (3)-(7) include interaction terms, described in the heading of each column above. In every case, both components of the interaction term appear in the regression

Given the bootstrapping procedure used to calculate standard errors, we omit some singleton observations in IV regressions

Please note, regressions on "tenure choice" and "propensity to move" make use of households that do not own at first observation only.

$\underline{\underline{\text { Panel B }}}$

(1)

Dependent variable: $\stackrel{(1)}{(2)}$ Household moves to a cheaper neighbourhood

Estimation technique: $\quad$ OLS IV IV Household recently Household recently Household is young Household has high Household has married had children

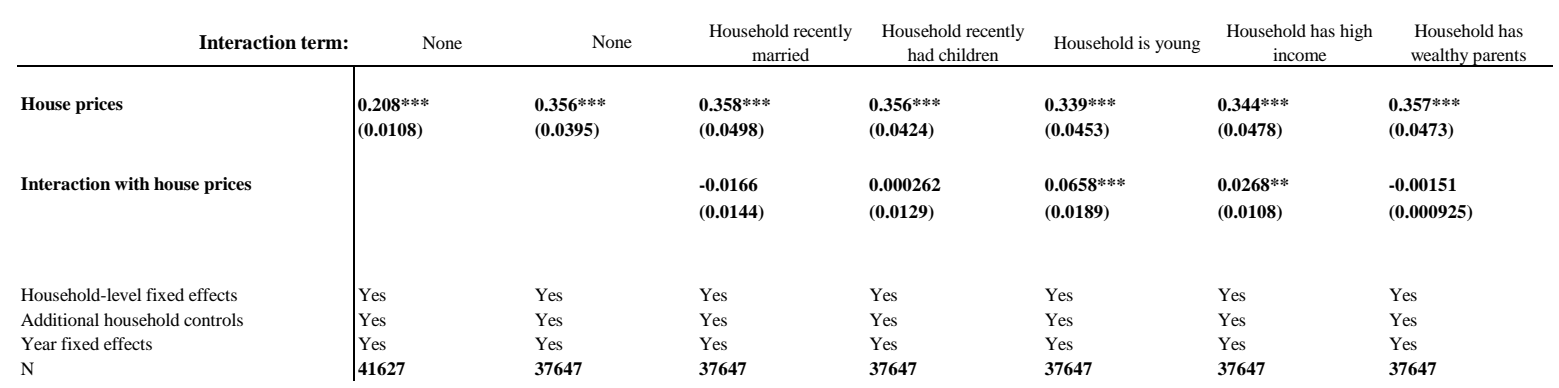

The table above regresses whether a household relocates to a cheaper area on various factors including log house prices.

House prices are $\log$ (single family home prices) as opposed to $\log ($ rental rates). Columns (1) is estimated using ordinary prices. Columns (2) - (7) are instrumented with pushed immigration. Standard errors are heteroscedasticity robust and bootstrapped with respect to the panel structure of the data.

Columns (3)-(7) include interaction terms, described in the heading of each column above. In every case, both components of the interaction term appear in the regression.

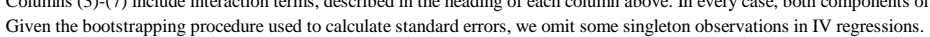

Please note, regressions on "tenure choice" and "propensity to move" make use of households that do not own at first observation only. 
Panel A

\begin{tabular}{|c|c|c|c|c|c|c|c|}
\hline \multirow[b]{2}{*}{ Estimation technique: } & \multicolumn{7}{|l|}{$\begin{array}{c}(1) \\
\text { Disposable income }\end{array}$} \\
\hline & OLS & IV & IV & IV & IV & IV & IV \\
\hline Interaction term: & None & None & Household owns & $\begin{array}{l}\text { Household owns at } \\
\text { first observation }\end{array}$ & $\begin{array}{l}\text { Household moves } \\
\text { while in sample }\end{array}$ & Household is young & $\begin{array}{l}\text { Household has } \\
\text { wealthy parents }\end{array}$ \\
\hline Rental Prices & $\begin{array}{l}-0.0217 * * * \\
(0.00666)\end{array}$ & $\begin{array}{l}-0.0883^{* *} \\
(0.0424)\end{array}$ & $\begin{array}{l}-0.0718^{*} \\
(0.0425)\end{array}$ & $\begin{array}{l}-0.0839 * * \\
(0.0427)\end{array}$ & $\begin{array}{l}-0.0634 \\
(0.0427)\end{array}$ & $\begin{array}{l}-0.0884^{* *} \\
(0.0423)\end{array}$ & $\begin{array}{l}-0.0884 * * \\
(0.0424)\end{array}$ \\
\hline Interaction with rental prices & & & $\begin{array}{l}0.191 * * * \\
(0.0128)\end{array}$ & $\begin{array}{l}0.0849 * * * \\
(0.0125)\end{array}$ & $\begin{array}{l}-0.0450^{* * *} \\
(0.0101)\end{array}$ & $\begin{array}{l}0.00265 \\
(0.0171)\end{array}$ & $\begin{array}{l}-0.000161 \\
(0.000424)\end{array}$ \\
\hline $\begin{array}{l}\text { Household-level fixed effects } \\
\text { Household and regional controls } \\
\text { Year fixed effects } \\
\text { N }\end{array}$ & $\begin{array}{l}\text { Yes } \\
\text { Yes } \\
\text { Yes } \\
\mathbf{5 4 9 0 9}\end{array}$ & $\begin{array}{l}\text { Yes } \\
\text { Yes } \\
\text { Yes } \\
\mathbf{4 7 6 4 7}\end{array}$ & $\begin{array}{l}\text { Yes } \\
\text { Yes } \\
\text { Yes } \\
\mathbf{4 7 6 4 7}\end{array}$ & $\begin{array}{l}\text { Yes } \\
\text { Yes } \\
\text { Yes } \\
\mathbf{4 7 6 4 7}\end{array}$ & $\begin{array}{l}\text { Yes } \\
\text { Yes } \\
\text { Yes } \\
\mathbf{4 7 6 4 7}\end{array}$ & $\begin{array}{l}\text { Yes } \\
\text { Yes } \\
\text { Yes } \\
\mathbf{4 7 6 4 7}\end{array}$ & $\begin{array}{l}\text { Yes } \\
\text { Yes } \\
\text { Yes } \\
\mathbf{4 7 6 4 7}\end{array}$ \\
\hline $\begin{array}{l}\text { The table above regresses consumable incon } \\
\text { The above table uses log rental prices as a p } \\
\text { immigration. We pre-estimate instruments ( } \\
\text { Columns (3) -(7) include interaction terms, } \\
\text { Given the bootstrapping procedure used to }\end{array}$ & $\begin{array}{l}\text { e (income less rental p } \\
\text { roxy for house prices. } \\
\text { louse price and interact } \\
\text { lescribed in the heading } \\
\text { alculate standard error }\end{array}$ & $\begin{array}{l}\text { Colices and taxe } \\
\text { tions of house } \\
\text { g of each colu } \\
\text { rs, we omit so }\end{array}$ & $\begin{array}{l}\text { proportion of total } \\
\text { nated using ordinary } \\
\text { with other characte } \\
\text { ove. In every case, } \\
\text { gleton observation }\end{array}$ & $\begin{array}{l}\text { lincome) on various } \mathrm{f} \\
\text { y prices. Columns (2) } \\
\text { eristics) for use as inst } \\
\text { both components of } t \\
\text { is in IV regressions. }\end{array}$ & $\begin{array}{l}\text { actors including log } \mathrm{l} \\
\text { - (7) are instrumente } \\
\text { truments in an IV frar } \\
\text { the interaction term a }\end{array}$ & $\begin{array}{l}\text { house prices. } \\
\mathrm{d} \text { with pushed } \\
\text { mework. } \\
\text { ppear in the regression. }\end{array}$ & \\
\hline
\end{tabular}

Panel B

\begin{tabular}{|c|c|c|c|c|c|c|c|}
\hline \multirow{2}{*}{$\begin{array}{l}\text { Dependent variable: } \\
\text { Estimation technique: }\end{array}$} & \multicolumn{2}{|c|}{$\begin{array}{l}\text { (1) } \\
\text { Consumption (index) }\end{array}$} & \multicolumn{2}{|r|}{ (4) } & (5) & (6) & \multirow[t]{2}{*}{ (7) } \\
\hline & OLS & IV & IV & IV & IV & IV & \\
\hline Interaction term & None & None & Household owns & $\begin{array}{l}\text { Household owns at } \\
\text { first observation }\end{array}$ & $\begin{array}{c}\text { Household moves } \\
\text { while in sample }\end{array}$ & Household is young & $\begin{array}{l}\text { Household has } \\
\text { wealthy parents }\end{array}$ \\
\hline Rental Prices & $\begin{array}{l}-0.127 \\
(0.0838)\end{array}$ & $\begin{array}{l}-1.063 * * \\
(0.488)\end{array}$ & $\begin{array}{l}-1.047 * * \\
(0.489)\end{array}$ & $\begin{array}{l}-1.054 * * \\
(0.488)\end{array}$ & $\begin{array}{l}-1.068 * * \\
(0.493)\end{array}$ & $\begin{array}{l}-1.064 * * \\
(0.488)\end{array}$ & $\begin{array}{l}-1.064^{* *} \\
(0.488)\end{array}$ \\
\hline Interaction with rental prices & & & $\begin{array}{l}0.900 * * * \\
(0.164)\end{array}$ & $\begin{array}{l}0.715^{* * *} \\
(0.144)\end{array}$ & $\begin{array}{l}0.0113 \\
(0.123)\end{array}$ & $\begin{array}{l}-0.812 * * * \\
(0.219)\end{array}$ & $\begin{array}{l}0.00185 \\
(0.00468)\end{array}$ \\
\hline $\begin{array}{l}\text { Household-level fixed effects } \\
\text { Household and regional controls } \\
\text { Year fixed effects } \\
\mathrm{N}\end{array}$ & $\begin{array}{l}\text { Yes } \\
\text { Yes } \\
\text { Yes } \\
\mathbf{5 4 7 7 2}\end{array}$ & $\begin{array}{l}\text { Yes } \\
\text { Yes } \\
\text { Yes } \\
\mathbf{5 2 0 6 1}\end{array}$ & $\begin{array}{l}\text { Yes } \\
\text { Yes } \\
\text { Yes } \\
\mathbf{5 2 0 6 1}\end{array}$ & $\begin{array}{l}\text { Yes } \\
\text { Yes } \\
\text { Yes } \\
\mathbf{5 2 0 6 1}\end{array}$ & $\begin{array}{l}\text { Yes } \\
\text { Yes } \\
\text { Yes } \\
\mathbf{5 2 0 6 1}\end{array}$ & $\begin{array}{l}\text { Yes } \\
\text { Yes } \\
\text { Yes } \\
\mathbf{5 2 0 6 1}\end{array}$ & $\begin{array}{l}\text { Yes } \\
\text { Yes } \\
\text { Yes } \\
\mathbf{5 2 0 6 1}\end{array}$ \\
\hline $\begin{array}{l}\text { The table above regresses an index of cons } \\
\text { The above table uses log rental prices as a } \\
\text { immigration. We pre-estimate instruments } \\
\text { Columns (3) - }(7) \text { include interaction terms, } \\
\text { Given the bootstrapping procedure used to }\end{array}$ & $\begin{array}{l}\text { Imption items (s } \\
\text { roxy for house } \\
\text { house price and } \\
\text { described in the } \\
\text { calculate standa }\end{array}$ & $\begin{array}{l}\text { cription in meth } \\
\text { Columns (1) is } \\
\text { ctions of house } \\
\text { ng of each colur } \\
\text { ors, we omit sol }\end{array}$ & $\begin{array}{l}\text { gy chapter) on var } \\
\text { ated using ordinar } \\
\text { with other charact } \\
\text { ove. In every case, } \\
\text { gleton observation }\end{array}$ & $\begin{array}{l}\text { ious factors including } \\
\text { y prices. Columns (2) } \\
\text { eristics) for use as inst } \\
\text { both components of t } \\
\text { is in IV regressions. }\end{array}$ & $\begin{array}{l}\text { log house prices. } \\
\text { - (7) are instrumente } \\
\text { truments in an IV frar } \\
\text { the interaction term a }\end{array}$ & $\begin{array}{l}\text { d with pushed } \\
\text { mework. } \\
\text { ppear in the regression. }\end{array}$ & \\
\hline
\end{tabular}


Panel A

$\begin{array}{llll}\text { (1) } & \text { (3) }\end{array}$

Dependent variable: Household transitions to ownership in following year

\begin{tabular}{|c|c|c|c|c|c|c|c|}
\hline Estimation technique: & OLS & IV & IV & IV & IV & IV & IV \\
\hline Interaction term: & None & None & $\begin{array}{l}\text { Household recently } \\
\text { married }\end{array}$ & $\begin{array}{l}\text { Household recently } \\
\text { had children }\end{array}$ & $\begin{array}{c}\text { Household is } \\
\text { young }\end{array}$ & $\begin{array}{l}\text { Household has high } \\
\text { income }\end{array}$ & $\begin{array}{l}\text { Household has } \\
\text { wealthy parents }\end{array}$ \\
\hline Rental Prices & $\begin{array}{l}-0.0604 * * * \\
(0.0148)\end{array}$ & $\begin{array}{l}-0.188 * * * \\
(0.0431)\end{array}$ & $\begin{array}{l}-0.0836 * \\
(0.0475)\end{array}$ & $\begin{array}{l}-0.0754 \\
(0.0473)\end{array}$ & $\begin{array}{l}-0.130 * * * \\
(0.0448)\end{array}$ & $\begin{array}{l}-0.181 * * * \\
(0.0488)\end{array}$ & $\begin{array}{l}-0.104 * * \\
(0.0464)\end{array}$ \\
\hline Interaction with rental prices & & & $\begin{array}{l}-0.165^{* * *} \\
(0.0442)\end{array}$ & $\begin{array}{l}-0.202 * * * \\
(0.0361)\end{array}$ & $\begin{array}{l}0.106 * * * \\
(0.0333)\end{array}$ & $\begin{array}{l}0.197 * * * \\
(0.0247)\end{array}$ & $\begin{array}{l}-0.00119 \\
(0.000967)\end{array}$ \\
\hline Household-level fixed effects & Yes & Yes & Yes & Yes & Yes & Yes & Yes \\
\hline Additional household controls & Yes & Yes & Yes & Yes & Yes & Yes & Yes \\
\hline Year fixed effects & Yes & Yes & Yes & Yes & Yes & Yes & Yes \\
\hline $\mathrm{N}$ & 41627 & 30346 & 30346 & 30346 & 30346 & 30346 & 30347 \\
\hline
\end{tabular}

The table above regresses whether a household transitions to ownership in the following year $(\mathrm{y}=1)$ on various factors including log house prices.

The above table uses log rental prices as a proxy for house prices. Columns (1) is estimated using ordinary prices. Columns (2) - (7) are instrumented with pushed

immigration. We pre-estimate instruments (house price and interactions of house price with other characteristics) for use as instruments in an IV framework.

Columns (3)-(7) include interaction terms, described in the heading of each column above. In every case, both components of the interaction term appear in the regression.

Given the bootstrapping procedure used to calculate standard errors, we omit some singleton observations in IV regressions.

Please note, regressions on "tenure choice" and "propensity to move" make use of households that do not own at first observation only.

Panel B

(2)

(3)

(4)

(5)

(6)

(7)

Dependent variable: Household moves to a cheaper neighbourhood

IV

IV

IV

IV

\begin{tabular}{|c|c|c|c|c|c|c|c|}
\hline Estimation technique: & OLS & IV & IV & IV & IV & IV & IV \\
\hline Interaction term: & None & None & $\begin{array}{l}\text { Household recently } \\
\text { married }\end{array}$ & $\begin{array}{l}\text { Household recently } \\
\text { had children }\end{array}$ & $\begin{array}{l}\text { Household is } \\
\text { young }\end{array}$ & $\begin{array}{l}\text { Household has high } \\
\text { income }\end{array}$ & $\begin{array}{l}\text { Household has } \\
\text { wealthy parents }\end{array}$ \\
\hline Interaction with rental prices & & & $\begin{array}{l}-0.0786 * * \\
(0.0329)\end{array}$ & $\begin{array}{l}-0.0284 \\
(0.0266)\end{array}$ & $\begin{array}{l}0.0996 * * * \\
(0.0318)\end{array}$ & $\begin{array}{l}0.0309 \\
(0.0197)\end{array}$ & $\begin{array}{l}-0.00254 * * * \\
(000806)\end{array}$ \\
\hline Household-level fixed effects & Yes & Yes & Yes & Yes & Yes & Yes & Yes \\
\hline Additional household controls & Yes & Yes & Yes & Yes & Yes & Yes & Yes \\
\hline Year fixed effects & Yes & Yes & Yes & Yes & Yes & Yes & Yes \\
\hline $\mathrm{N}$ & 41627 & 35687 & 35687 & 35687 & 35687 & 35687 & 35687 \\
\hline
\end{tabular}

The table above regresses whether a household relocates to a cheaper area on various factors including log house prices.

The above table uses log rental prices as a proxy for house prices. Columns (1) is estimated using ordinary prices. Columns (2) - (7) are instrumented with pushed

immigration. We pre-estimate instruments (house price and interactions of house price with other characteristics) for use as instruments in an IV framework.

Columns (3)-(7) include interaction terms, described in the heading of each column above. In every case, both components of the interaction term appear in the regression.

Given the bootstrapping procedure used to calculate standard errors, we omit some singleton observations in IV regressions.

Please note, regressions on "tenure choice" and "propensity to move" make use of households that do not own at first observation only. 
Panel A

$\begin{array}{lllllllll}1 & \text { (1) } & \text { (3) } & \text { (4) } & \text { (5) } & \text { (7) }\end{array}$

Dependent variable: Household transitions to ownership in following year

IV IV

IV IV

IV

IV

\begin{tabular}{|c|c|c|c|c|c|c|c|}
\hline Interaction term: & None & None & $\begin{array}{l}\text { Household recently } \\
\text { married }\end{array}$ & $\begin{array}{l}\text { Household recently } \\
\text { had children }\end{array}$ & Household is young & $\begin{array}{l}\text { Household has high } \\
\text { income }\end{array}$ & $\begin{array}{l}\text { Hol } \\
\text { wea }\end{array}$ \\
\hline Rental Prices & \begin{tabular}{|l}
$-0.0150 *$ \\
$(0.00800)$
\end{tabular} & $\begin{array}{l}-0.0901 * * \\
(0.0399)\end{array}$ & $\begin{array}{l}-0.0898 * * \\
(0.0411)\end{array}$ & $\begin{array}{l}-0.0855 * * \\
(0.0380)\end{array}$ & $\begin{array}{l}-0.0883 * * * \\
(0.0313)\end{array}$ & $\begin{array}{l}-0.0889 * * \\
(0.0389)\end{array}$ & $\begin{array}{r}-0.093 \\
(0.038\end{array}$ \\
\hline Interaction with rental prices & & & $\begin{array}{l}-0.0361^{*} \\
(0.0193)\end{array}$ & $\begin{array}{l}-0.0598^{* * *} \\
(0.0146)\end{array}$ & $\begin{array}{l}0.0159 \\
(0.0113)\end{array}$ & $\begin{array}{l}-0.00407 \\
(0.00767)\end{array}$ & $\begin{array}{l}0.0007 \\
(0.000\end{array}$ \\
\hline Household-level fixed effects & No & No & No & No & No & No & No \\
\hline Additional household controls & Yes & Yes & Yes & Yes & Yes & Yes & Yes \\
\hline Year fixed effects & Yes & Yes & Yes & Yes & Yes & Yes & Yes \\
\hline $\mathrm{N}$ & 41627 & 30346 & 30346 & 30346 & 30346 & 30346 & 3034 \\
\hline
\end{tabular}

The table above regresses whether a household transitions to ownership in the following year $(y=1)$ on various factors including log house prices.

The above table uses log rental prices as a proxy for house prices. Columns (1) is estimated using ordinary prices. Columns (2) - (7) are instrumented with pushed

immigration. Standard errors are heteroscedasticity robust and bootstrapped with respect to the panel structure of the data.

Columns (3)-(7) include interaction terms, described in the heading of each column above. In every case, both components of the interaction term appear in the regression.

Given the bootstrapping procedure used to calculate standard errors, we omit some singleton observations in IV regressions

Please note, regressions on "tenure choice" and "propensity to move" make use of households that do not own at first observation only.

$\underline{\underline{\text { Panel B }}}$

(1)

Dependent variable: Household moves to a cheaper neighbourhood

Estimation technique: $\quad$ OLS IV IV IV

\begin{tabular}{|c|c|c|c|c|c|c|c|}
\hline Estimation technique: & OLS & IV & IV & IV & IV & IV & IV \\
\hline Interaction term: & None & None & $\begin{array}{c}\text { Household recently } \\
\text { married }\end{array}$ & $\begin{array}{l}\text { Household recently } \\
\text { had children }\end{array}$ & Household is young & $\begin{array}{l}\text { Household has high } \\
\text { income }\end{array}$ & $\begin{array}{l}\text { Household has } \\
\text { wealthy parents }\end{array}$ \\
\hline Interaction with rental prices & & & $\begin{array}{l}0.0174 \\
(0.0201)\end{array}$ & $\begin{array}{l}-0.00484 \\
(0.0124)\end{array}$ & $\begin{array}{l}0.00744 \\
(0.0151)\end{array}$ & $\begin{array}{l}-0.00186 \\
(0.0101)\end{array}$ & $\begin{array}{l}0.0000411 \\
(0.000193)\end{array}$ \\
\hline Household-level fixed effects & No & No & No & No & No & No & No \\
\hline Additional household controls & Yes & Yes & Yes & Yes & Yes & Yes & Yes \\
\hline Year fixed effects & Yes & Yes & Yes & Yes & Yes & Yes & Yes \\
\hline $\mathrm{N}$ & 41627 & 35687 & 35687 & 35687 & 35687 & 35687 & 35687 \\
\hline
\end{tabular}

The table above regresses whether a household relocates to a cheaper area on various factors including log house prices.

The above table uses the price of single family homes as a proxy for house prices. Columns (1) is estimated using ordinary prices. Columns (2) - (7) are instrumented with pushed immigration. Standard errors are heteroscedasticity robust and bootstrapped with respect to the panel structure of the data

Columns (3)-(7) include interaction terms, described in the heading of each column above. In every case, both components of the interaction term appear in the regression.

Given the bootstrapping procedure used to calculate standard errors, we omit some singleton observations in IV regressions.

Please note, regressions on "tenure choice" and "propensity to move" make use of households that do not own at first observation only. 
Dependent variable: Log of single family house prices

\section{Estimation technique:}

Spatial lag

Immigrants from Western Europe

Immigrants from other OECD countries

Immigrants from Eastern Europe

Rest of the World

Region and Year fixed effects

Additional region controls

$\mathrm{N}$

The above regression relates log house prices to immigration.

We split immigration along various dimensions relating to the residency permit

We estimate our results using a SAR model.
SAR

$0.81^{* * *}$

(0.0029)

$0.815290^{* * *}$

(0.0457)

$5.630153^{* * *}$

(0.3793)

$0.431212^{* * *}$

(0.0613)

$0.186740 *$

(0.0733)

Yes

Yes

51106 